\title{
Tranexamic acid concentrations associated with human seizures inhibit glycine receptors
}

\author{
Irene Lecker, ${ }^{1}$ Dian-Shi Wang, ${ }^{1}$ Alexander D. Romaschin, ${ }^{2}$ Mark Peterson, ${ }^{3}$ \\ C. David Mazer, ${ }^{1,4,5}$ and Beverley A. Orser ${ }^{1,4,6}$
}

\begin{abstract}
1Department of Physiology, University of Toronto, Toronto, Ontario, Canada. 2Department of Laboratory Medicine and Pathobiology and ${ }^{3}$ Department of Surgery, St. Michael's Hospital, University of Toronto, Toronto, Ontario, Canada. ${ }^{4}$ Department of Anaesthesia, University of Toronto, Toronto, Ontario, Canada. ${ }^{5}$ Keenan Research Centre in the Li Ka Shing Knowledge Institute, St. Michael's Hospital, Toronto, Ontario, Canada. ${ }^{6}$ Department of Anaesthesia, Sunnybrook Health Sciences Centre, Toronto, Ontario, Canada.
\end{abstract}

\begin{abstract}
Antifibrinolytic drugs are widely used to reduce blood loss during surgery. One serious adverse effect of these drugs is convulsive seizures; however, the mechanisms underlying such seizures remain poorly understood. The antifibrinolytic drugs tranexamic acid (TXA) and $\varepsilon$-aminocaproic acid (EACA) are structurally similar to the inhibitory neurotransmitter glycine. Since reduced function of glycine receptors causes seizures, we hypothesized that TXA and EACA inhibit the activity of glycine receptors. Here we demonstrate that TXA and EACA are competitive antagonists of glycine receptors in mice. We also showed that the general anesthetic isoflurane, and to a lesser extent propofol, reverses TXA inhibition of glycine receptor-mediated current, suggesting that these drugs could potentially be used to treat TXA-induced seizures. Finally, we measured the concentration of TXA in the cerebrospinal fluid (CSF) of patients undergoing major cardiovascular surgery. Surprisingly, peak TXA concentration in the CSF occurred after termination of drug infusion and in one patient coincided with the onset of seizures. Collectively, these results show that concentrations of TXA equivalent to those measured in the CSF of patients inhibited glycine receptors. Furthermore, isoflurane or propofol may prevent or reverse TXA-induced seizures.
\end{abstract}

\section{Introduction}

Antifibrinolytic drugs are widely used to reduce blood loss in a variety of hemorrhagic conditions, including severe trauma (1), cardiac and non-cardiac surgery (2-5), and maternal hemorrhage (6). Safe and effective pharmacological blood conservation strategies are needed, as the risks and costs associated with allogenic blood transfusions continue to increase $(7,8)$. Such pharmacological treatments for hemorrhage are particularly important in developing nations, where blood banking facilities are limited, the risk of blood-borne infection is high, and the number of trauma-related deaths is rapidly rising (9).

Tranexamic acid (TXA) and $\varepsilon$-aminocaproic acid (EACA) are widely used antifibrinolytics (10). These two lysine analogs exert their antifibrinolytic effects by inhibiting the activation of plasminogen, thereby preventing degradation of fibrin and dissolution of clots (11). Another commonly used antifibrinolytic drug, aprotinin (a serine protease inhibitor derived from bovine lung), is structurally different from TXA and EACA. Aprotinin prevents blood loss by directly antagonizing plasmin (12). Aprotinin was suspended from the market because of reports of a higher incidence of death and renal dysfunction (13-15). Consequently, reliance on TXA and EACA will remain high for the foreseeable future.

TXA and EACA evoke seizures in both laboratory animals and patients, but the mechanisms underlying these seizures have not been clearly elucidated. Direct application of TXA to the cortex of cats (16) and intrathecal and intravenous administration of this drug to rats evoke convulsive and proconvulsive behaviors $(17,18)$. In patients, generalized tonic-clonic seizures have occurred after inadvertent intrathecal injection of TXA (19-21) and after intravenous administrations of EACA (22).

Conflict of interest: The authors have declared that no conflict of interest exists. Citation for this article: J Clin Invest. 2012;122(12):4654-4666. doi:10.1172/JCI63375.
More recently, TXA has been associated with an increased incidence of postoperative seizures in cardiac patients $(23,24)$. Historically, postoperative seizures have occurred in about $0.5 \%-1 \%$ of cardiac patients $(25,26)$, but the use of higher doses of TXA has been associated with a higher incidence of seizures $(2.7 \%-7.6 \%)$ $(27,28)$, primarily of the grand mal type $(23,29)$. The frequency of seizures is higher among patients with preoperative renal failure, patients undergoing open heart surgery, and older patients (30). These seizures typically occur within hours of the patient being transferred from the operating room to the intensive care unit, when the concentrations of anesthetic are declining rapidly and TXA levels remain high (29). Such postoperative seizures constitute a serious adverse effect, because they may be associated with an increased incidence of neurological complications (including delirium and stroke) (31), prolongation of recovery times, and higher mortality rates $(25,31)$. Currently, there are no mechanism-based treatments or prevention strategies for seizures associated with TXA or EACA.

Both TXA and EACA are structural analogs of the amino acid glycine, a major inhibitory neurotransmitter in the brain and spinal cord (Figure 1). Analogs of glycine may act as competitive antagonists, occupying the glycine-binding site and preventing glycine from binding to and activating its receptor. Glycine receptors are predominantly expressed in the spinal cord and brain stem but are also widely expressed in the prefrontal cortex, the hippocampus, and the amygdala (32). These receptors are pentameric chloride ion channels that are composed of $\alpha_{1-4}$ and $\beta$ subunits (33). The subunit composition of each receptor determines its pharmacological properties, as well as its expression patterns in the CNS and the subcellular regions of neurons (34).

Glycine receptors in the CNS mediate two distinct forms of inhibition: postsynaptic and tonic (32). Postsynaptic inhibitory currents are generated by glycine receptors clustered in the postsynaptic ter- 


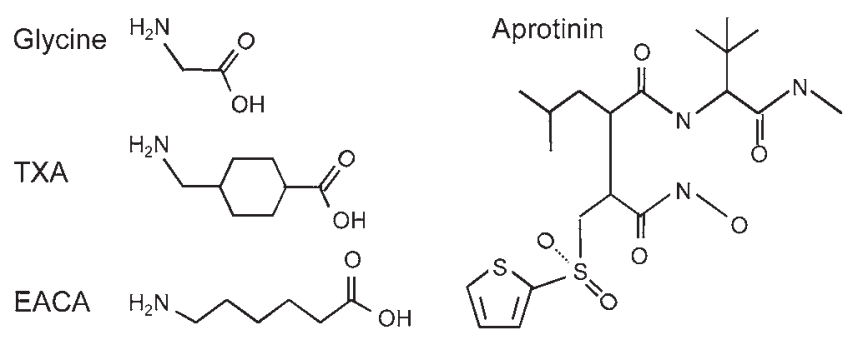

Figure 1

Molecular structures of glycine and the antifibrinolytic drugs TXA, EACA, and aprotinin.

minal, which are activated by the synchronous release of high concentrations of glycine (35). Tonic glycine currents mediate a "paracrine" form of inhibition that is generated by extrasynaptic glycine receptors, which are activated by low, ambient concentrations of glycine spilling over from the synaptic cleft or by glycine that is released by non-vesicular mechanisms (35). A tonic glycinergic inhibitory conductance has been identified in the hypothalamus, the hippocampus, and the dorsal horn of the spinal cord (36). The pharmacological and physiological properties of glycine receptors that generate postsynaptic and tonic inhibition may differ considerably (37).

Since drugs that inhibit glycine receptors are known to induce seizures, we tested the hypothesis that TXA and EACA, but not aprotinin, competitively inhibit glycine receptor function. Of the 3 antifibrinolytic drugs, we most thoroughly investigated the properties of TXA, as it is widely used. As predicted for a competitive antagonist, we anticipated that tonic inhibitory current, evoked by low concentrations of extracellular glycine, would be more sensitive than postsynaptic currents to TXA blockade. In addition, while the primary focus of this study was on TXA modulation of glycine receptors, we also studied the potency of TXA inhibition of $\gamma$-aminobutyric acid type $A\left(G_{A B A}\right)$ receptors. $G_{A B A}$ receptors are major mediators of inhibition in the CNS and were previously shown to be competitively inhibited by TXA when expressed recombinantly in human embryonic kidney cells (38). Here, we directly compare TXA blockade of native glycine and $\mathrm{GABA}_{\mathrm{A}}$ receptors in cortical and spinal cord neurons.

We also sought to identify a strategy to reverse the inhibitory effect of TXA on glycine receptors. Given that anesthetics, including isoflurane and propofol, allosterically potentiate glycine receptor activity (39-41), and seizures frequently occur during emergence from anesthesia (29), we hypothesized that these drugs would reverse or attenuate inhibition of glycine receptors by TXA. We also studied the proconvulsant properties of TXA in neocortical slices and anticipated that anesthetics would attenuate TXAinduced enhancement of network excitability.

Finally, to determine whether glycine receptors represent clinically relevant targets for TXA, we measured the concentration of TXA in the cerebrospinal fluid (CSF) of patients. CSF samples were obtained at different surgical time points from patients undergoing surgical repair of thoraco-abdominal aortic pathology. This surgical procedure was selected because it involves insertion of a catheter into the lumbar intrathecal space, to drain the CSF and thereby improve blood flow in the spinal cord and reduce neurological damage $(42,43)$. The results show that glycine receptors, particularly those activated by a low concentration of glycine, are inhibited by concentrations of TXA that occur in the CSF of patients.

\section{Results}

TXA is a competitive antagonist of glycine receptors. TXA is a structural analog of glycine, which suggests that it may compete for the glycine-binding site and thereby inhibit glycine receptor function. The effects of TXA on glycine receptors were studied using mouse neurons grown in dissociated cell cultures. Primary cultures of mouse neurons are a suitable experimental model, because the glycine receptors of mice are remarkably similar to those of humans (32). All glycine-evoked currents were recorded in the presence of the $\mathrm{GABA}_{\mathrm{A}}$ receptor antagonist bicuculline $(10 \mu \mathrm{M})$. First, the concentration of glycine that evoked the half-maximal current $\left(\mathrm{EC}_{50}\right)$ in cortical neurons was determined to be $95.7 \pm 16.2 \mu \mathrm{M}(n=4-6$; Supplemental Figure 1A; supplemental material available online with this article; doi:10.1172/JCI63375DS1). Next, the effect of TXA on current evoked by a glycine concentration near the $\mathrm{EC}_{50}$ $(100 \mu \mathrm{M})$ was studied. Coapplication of TXA $(0.01-30 \mathrm{mM})$ and glycine caused a rapid and reversible decrease in current amplitude (Figure 2A). The half-maximal inhibitory concentration of TXA $\left(\mathrm{IC}_{50}\right)$ was $1.1 \pm 0.1 \mathrm{mM}$ (estimated Hill coefficient $[n \mathrm{H}]$ value $=$ $1.4 \pm 0.04, n=6-8$; Figure 2A).

TXA inhibition of glycine current was similar whether TXA was pre- or coapplied with glycine (Supplemental Figure 2). Also, TXA alone did not elicit any current (data not shown), which indicates that TXA does not act as an agonist at glycine receptors. TXA caused a slight reduction in the rate and extent of current desensitization (Supplemental Figure 3). However, desensitization in the presence of TXA was similar to that observed when glycine receptors were activated by a lower concentration of glycine alone. This latter observation suggests that TXA does not directly modulate glycine receptor desensitization.

To further determine whether TXA acts as a competitive antagonist, glycine concentration response plots were generated for currents recorded in the absence or presence of TXA (Figure 2B). TXA ( 1 and $10 \mathrm{mM}$ ) shifted the glycine concentration response plot to the right without reducing the maximal response. More specifically, TXA $(1 \mathrm{mM})$ increased the glycine $\mathrm{EC}_{50}$ from $93.9 \pm 6.8 \mu \mathrm{M}$ to $207.1 \pm 38.9 \mu \mathrm{M}(n=6-7)$. TXA $(10 \mathrm{mM})$ further increased the glycine $\mathrm{EC}_{50}$ to $788.6 \pm 13.1 \mu \mathrm{M}(n=6-7)$. Schild regression analysis yielded a slope similar to unity (slope $=0.81, n=6-7$; Figure $2 \mathrm{~B}$, inset), which indicates that TXA is a competitive antagonist.

We next tested whether TXA inhibition of glycine receptors exhibited use or voltage dependence, as observed for noncompetitive antagonists that preferentially bind to the open state of the channel (44). The onset of TXA inhibition was not use dependent, and recovery from blockade was reversed immediately after TXA washout (Figure 3A). The degree of TXA inhibition was only slightly greater at negative holding potentials than positive holding potentials, as evidenced by the outward rectification of the current-voltage plot in the presence of TXA (Figure 3B). This apparent voltage sensitivity of TXA inhibition was attributed to the voltage sensitivity of glycine receptors being activated by lower concentrations of the agonist (45), because in the absence of TXA, a low concentration of glycine $(30 \mu \mathrm{M})$ also produced a slight outward rectification of the current-voltage plot (Figure $3 \mathrm{~B}$ ). These results are consistent with the interpretation that TXA is a competitive antagonist of glycine receptors.

EACA, but not aprotinin, in bibits glycine receptors. Like TXA, EACA may also antagonize glycine receptors. Coapplication of EACA $(10 \mathrm{mM})$ and glycine $(100 \mu \mathrm{M})$ rapidly and reversibly inhibited the glycine-evoked current (Figure 4A). The concentration-response 

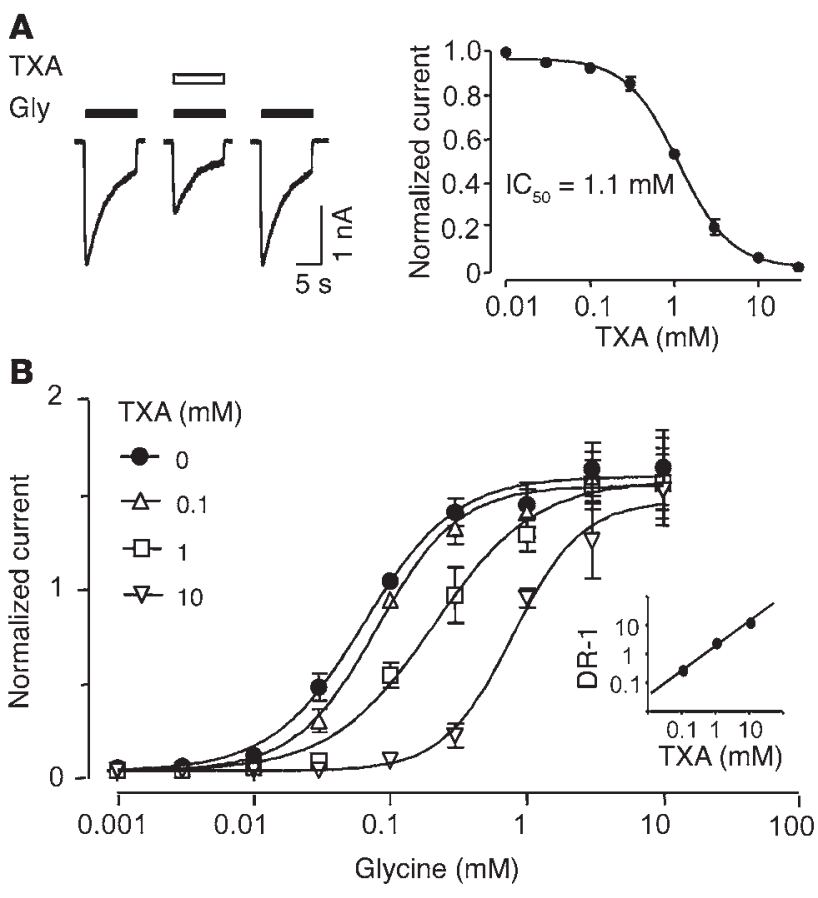

plot for EACA blockade of glycine currents revealed an $\mathrm{IC}_{50}$ of $12.3 \pm 0.9 \mathrm{mM}$ and $n \mathrm{H}$ of $1.5 \pm 0.1(n=5-6$; Figure $4 \mathrm{~A})$. Notably, the potency of EACA was 10-fold lower than that of TXA (TXA $\mathrm{IC}_{50}=1.1 \pm 0.1 \mathrm{mM}$; Figure $2 \mathrm{~A}$ ). EACA caused a rightward shift in the glycine concentration-response plot without reducing the maximal response (Figure 4B).

The effect of aprotinin on glycine receptor function was also investigated. Aprotinin was studied at lower concentrations, as its potency in terms of antifibrinolytic effect is greater than that of TXA or EACA (46). Aprotinin applied at concentrations as high as $100 \mu \mathrm{M}$ did not inhibit glycine receptor function (Figure 4C).

TXA inbibits glycine receptors in spinal cord neurons. Glycine receptors expressed in the spinal cord may exhibit pharmacological properties different from those of glycine receptors expressed in the

\section{Figure 2}

TXA is a competitive antagonist of glycine receptors. (A) TXA (1 mM) inhibits glycine $(100 \mu \mathrm{M})$-activated currents in cortical neurons. The corresponding concentration-response plot shows $\mathrm{IC}_{50}=1.1 \pm 0.1 \mathrm{mM}$ $(n=6-8)$. Here, and in subsequent figures, pA and nA stand for picoamperes and nanoamperes, respectively. (B) Concentration-response plots for glycine current recorded in the absence and presence of TXA. All values were normalized to currents evoked by glycine $(100 \mu \mathrm{M})$. The $\mathrm{EC}_{50}$ values and Hill coefficients for TXA $(0,0.1,1,10 \mathrm{mM})$ were $0.094 \pm 0.007 \mathrm{mM}$ and $1.4 \pm 0.2 ; 0.079 \pm 0.009 \mathrm{mM}$ and $1.4 \pm 0.2$; $0.21 \pm 0.038 \mathrm{mM}$ and $1.2 \pm 0.2$; and $0.79 \pm 0.013 \mathrm{mM}$ and $1.7 \pm 0.4$, respectively $(n=6-7)$. The Schild plot (inset) was generated by calculating the dose-response ratios (DR-1) of the EC50 of TXA divided by the EC50 of glycine for each concentration of TXA. The plot is consistent with a slope near $1\left(r^{2}=0.81\right)$ and a dissociation constant of $0.73 \mathrm{mM}$. Data are mean \pm SEM.

cortex (35). Therefore, we next investigated the effect of TXA on glycine receptors in spinal cord neurons. In addition, cultures of spinal cord neurons offer the experimental advantage of a relatively high-throughput model to study the effects of TXA on postsynaptic glycinergic currents as well as currents activated by low and high concentrations of exogenous glycine (37). The $\mathrm{EC}_{50}$ of glycine in spinal cord neurons was determined to be $34.9 \pm 14.6 \mu \mathrm{M}(n=5$, Supplemental Figure 1A). TXA rapidly and reversibly inhibited the current evoked by glycine $(30 \mu \mathrm{M})\left(\mathrm{IC}_{50}=1.4 \pm 0.1 \mathrm{mM}, n \mathrm{H}=1.5 \pm 0.03\right.$, $n=6$; Supplemental Figure 4).

To evaluate inhibition by TXA of glycine receptors under more physiologically relevant conditions, we studied glycinergic miniature inhibitory postsynaptic currents (mIPSCs). The competitive glycine receptor antagonist strychnine $(1 \mu \mathrm{M})$ completely abolished all mIPSCs $(n=6$; Figure 5A), confirming that the currents were generated by glycine receptors, as shown previously (47). Relatively low concentrations of TXA $(10$ and $100 \mu \mathrm{M})$ did not inhibit the mIPSCs, whereas a higher concentration of TXA $(1 \mathrm{mM})$ decreased the amplitude, decay time, area, and charge transfer of these currents (Figure 5 and Table 1).

Next, we investigated the effects of TXA on currents evoked by a low concentration of glycine $\left(\mathrm{EC}_{6}=10 \mu \mathrm{M}\right)$ under conditions intended to mimic the tonic glycine current recorded in spinal cord

\section{Figure 3}

TXA inhibition of glycine receptors is not use or voltage dependent. (A) Repeated application of TXA (1 mM) does not cause an increasing block of glycine $(100 \mu \mathrm{M})$-evoked currents. The bar graph shows mean peak amplitude of the current recorded with and without coapplication of TXA. Current recorded during the sequential application of TXA is identified in the bars as 1,2 , and $3(n=6)$. (B) Currents evoked by glycine (100 and $30 \mu \mathrm{M})$ in the absence and presence of TXA (1 $\mathrm{mM})$ were recorded at two holding potentials. The currentvoltage plot shows that TXA causes an outward rectification of glycine $(100 \mu \mathrm{M})$ current-voltage plot and that glycine $(30 \mu \mathrm{M})$ produced a similar modest outward rectification $(n=5-6)$. All values were normalized to glycine current activated by $100 \mu \mathrm{M}$ at $-60 \mathrm{mV}$. Data are mean \pm SEM.
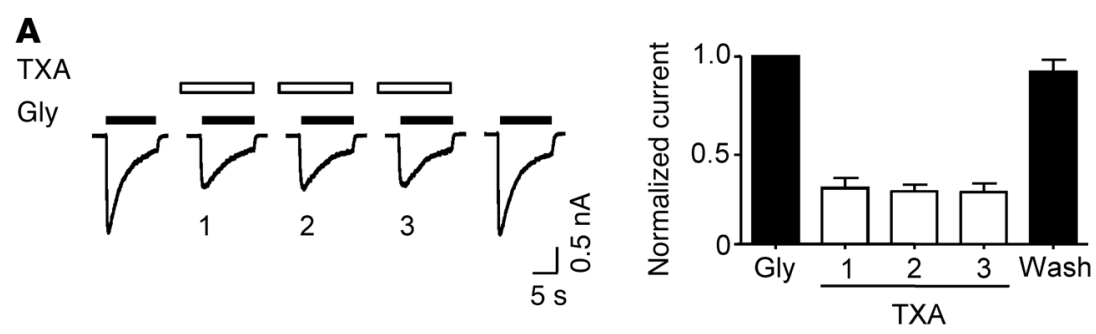

B

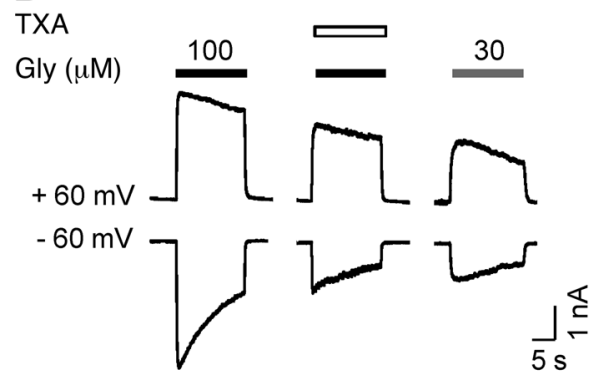


A

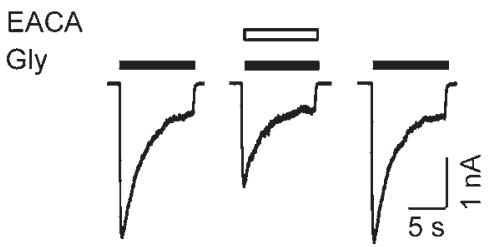

B

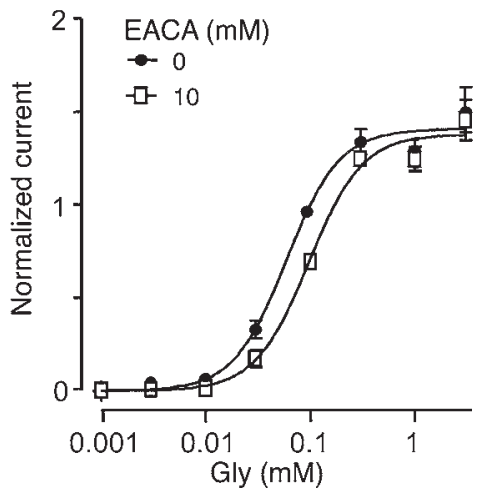

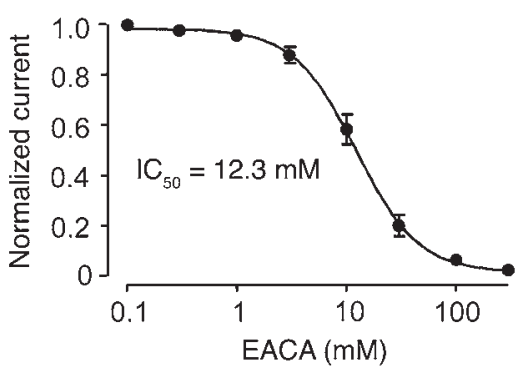

C
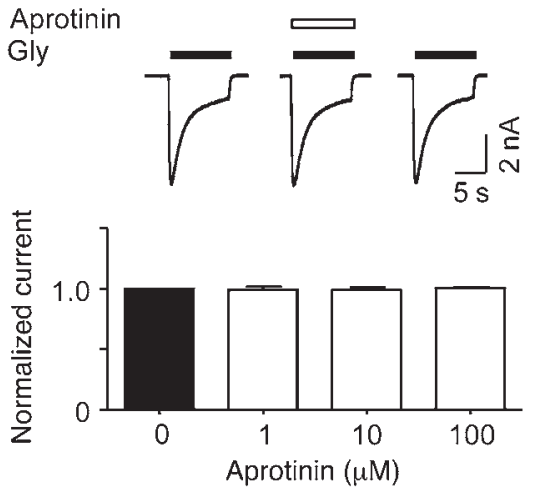

Figure 4

EACA competitively inhibits glycine receptors, whereas aprotinin does not. (A) Inhibition of glycine $(100 \mu \mathrm{M})$-activated current by EACA $(10 \mathrm{mM})$ in cortical neurons. The corresponding concentrationresponse plot shows $\mathrm{IC}_{50}=12.3 \pm 0.9 \mathrm{mM}(n=5-6)$. (B) Plots for current recorded in the absence and presence of EACA $(10 \mathrm{mM})$ show a rightward shift in the presence of EACA. The $E_{50}$ values and Hill coefficients for EACA were $134.1 \pm 4.7 \mu \mathrm{M}$ and $1.7 \pm 0.2$, respectively $(n=5-6)$. All values were normalized to currents evoked by glycine $(100 \mu \mathrm{M})$. (C) Aprotinin $(100 \mu \mathrm{M})$ has no effect on glycine $(100 \mu \mathrm{M})-$ evoked current in cortical neurons. The graph shows that aprotinin $(1-100 \mu \mathrm{M})$ failed to inhibit glycineevoked current $(n=5)$. Data are mean \pm SEM. slices $(33,48,49)$. Current amplitude was studied by applying strychnine $(1 \mu \mathrm{M})$ and measuring the reduction in holding current, as described previously $(36,50)$. In the absence of TXA, the amplitude of the glycine-evoked current was $187.2 \pm 54.3 \mathrm{pA}(n=12$; Figure $6 \mathrm{~A})$. TXA caused a rapid, reversible, concentration-dependent decrease in the current $\left(\mathrm{IC}_{50}=93.1 \pm 2.7 \mu \mathrm{M}, n=6-8\right.$; Figure 6 , $\mathrm{A}$ and $\left.\mathrm{B}\right)$.
Also, the variance of the baseline current noise regulates network excitability (51). Thus, we examined the effects of TXA on the baseline noise. TXA at concentrations as low as $10 \mu \mathrm{M}$ reduced the variance of the noise (baseline: $20.2 \pm 2.1 \mathrm{pA}$ versus TXA: $16.1 \pm 1.9 \mathrm{pA}$, $n=5-7$; Figure 6C). In some recordings, a transient, small-amplitude, inward "rebound" current was observed after termination of

\section{Figure 5}

TXA inhibits glycinergic mIPSCs at higher concentrations. (A) Glycinergic mIPSCs recorded from a spinal cord neuron, in the absence and presence of TXA. Application of strychnine abolished all glycinergic mIPSCs. pC stands for picocoloumbs. (B) Cumulative frequency plots for mIPSCs show the effect of TXA on the amplitude and inter-event interval. TXA (1 mM) significantly decreased the amplitude of the mIPSCs (left panel) without affecting the inter-event interval (right panel). (C) Average traces from 100 individual mIPSCs before and after application of TXA (1 $\mathrm{mM})$. Data for $\mathbf{A}-\mathbf{C}$ were obtained from the same spinal cord neuron. (D) TXA (1 mM) significantly decreased charge transfer of glycinergic mIPSCs, whereas lower concentrations had no significant effect $(n=5)$. ${ }^{*} P<0.05,{ }^{* *} P<0.01$ versus 0 TXA. Data are mean \pm SEM.

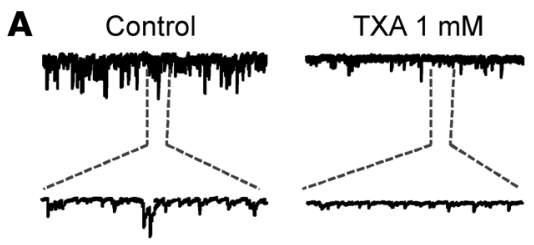

$\mathbf{B}$

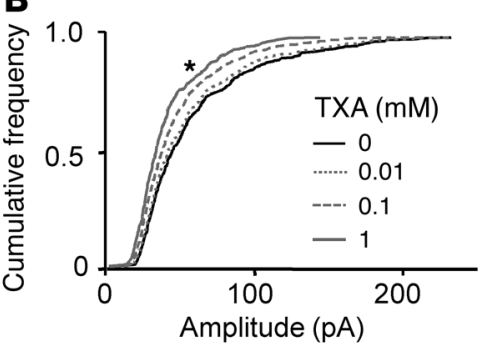

C
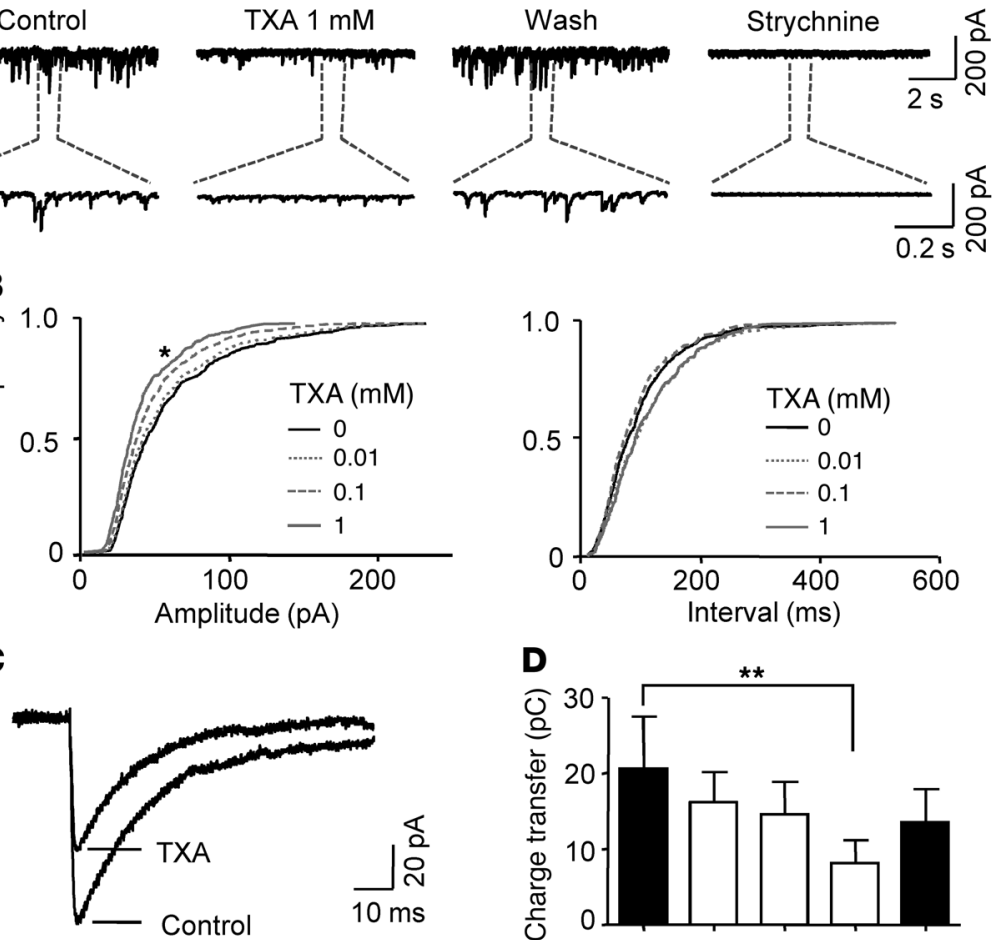

D

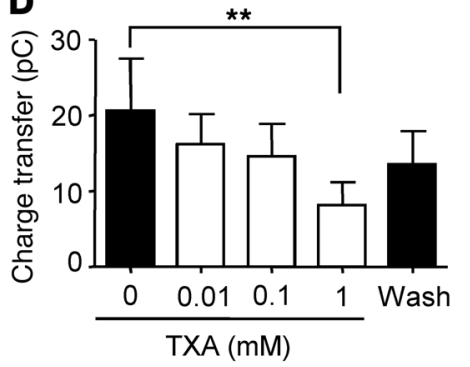


Table 1

The parameters of miniature inhibitory postsynaptic currents (mIPSCs) measured before and after application of TXA

\begin{tabular}{lccccccc}
\hline & & & & & & & \\
& Dose & Amplitude $(\mathbf{p A})$ & Frequency $(\mathrm{Hz})$ & Rise time $(\mathbf{m s})$ & Decay time $(\mathbf{m s})$ & Area $(\mathbf{p A} \times \mathbf{m s})$ & Charge transfer $(\mathbf{p C})$ \\
Control & & $138.1 \pm 49.2$ & $1.6 \pm 0.1$ & $2.4 \pm 0.4$ & $11.9 \pm 2.1$ & $1267.1 \pm 405.2$ & $20.1 \pm 6.8$ \\
TXA & $10 \mu \mathrm{M}$ & $110.7 \pm 26.9$ & $1.5 \pm 0.1$ & $2.1 \pm 0.2$ & $12.6 \pm 2.1$ & $1105.0 \pm 293.8$ & $16.2 \pm 3.9$ \\
& $100 \mu \mathrm{M}$ & $97.1 \pm 26.3$ & $1.6 \pm 0.1$ & $2.2 \pm 0.3$ & $11.6 \pm 1.6$ & $910.1 \pm 260.8$ & $14.6 \pm 4.3$ \\
& $1 \mathrm{mM}$ & $69.9 \pm 22.4^{\mathrm{A}}$ & $1.5 \pm 0.1$ & $2.5 \pm 0.4$ & $8.5 \pm 1.5^{\mathrm{B}}$ & $524.2 \pm 175.1^{\mathrm{B}}$ & $8.1 \pm 2.9^{\mathrm{B}}$ \\
\hline
\end{tabular}

Data are mean \pm SEM, $n=5 .{ }^{A} P<0.05,{ }^{B} P<0.01$ compared with control.

TXA application. This rebound current was attributed to glycine receptors that were recovering from desensitization (52), as a similar rebound phenomenon has been reported for competitive antagonists of $\mathrm{GABA}_{\mathrm{A}}$ receptors (53). Thus, the current amplitude and the variance of the noise of the tonic glycine current were highly sensitive to TXA inhibition with the highest potency for glycine current evoked by low concentrations of agonist.

TXA inbibits $G A B A_{A}$ receptors in cortical and spinal cord neurons. Since TXA was previously shown to inhibit recombinant $\mathrm{GABA}_{\mathrm{A}}$ receptors expressed in human embryonic kidney cells $\left(\mathrm{IC}_{50}=7.1 \mathrm{mM}\right)(38)$, we next examined the effect of TXA on native $\mathrm{GABA}_{\mathrm{A}}$ receptors in both cortical and spinal cord neurons. First, the $\mathrm{EC}_{50}$ of GABA was determined to be $19.7 \pm 2.3 \mu \mathrm{M}(n=4-6)$ in cortical neurons and $23.9 \pm 2.4 \mu \mathrm{M}(n=5-7)$ in spinal cord neurons (Supplemental Figure $1 \mathrm{~B})$. Next, the $\mathrm{IC}_{50}$ for TXA inhibition of GABA currents evoked by concentrations near $\mathrm{EC}_{50}$ values were found to be $1.5 \pm 0.1 \mathrm{mM}$ $(n=4-6)$ in both cortical and spinal cord neurons (Figure 7A).

We next investigated the effect of TXA on $\mathrm{GABA}_{\mathrm{A}}$ receptors activated by a low concentration of GABA $\left(\mathrm{EC}_{4}=1 \mu \mathrm{M}\right)$, since a tonic $\mathrm{GABA}_{\mathrm{A}}$ receptor-mediated current has been described in the spinal cord (54), cortex (55), and several other regions in the CNS (56). This low concentration of GABA was selected because it is near the extracellular or ambient concentration of GABA measured previously (57). The amplitude of the "tonic current" was studied by applying bicuculline $(100 \mu \mathrm{M})$ and measuring the reduction in holding current $(56,58)$. TXA inhibited currents evoked by a low concentration of GABA in both cortical neurons $\left(\mathrm{IC}_{50}=1.0 \pm 0.1 \mathrm{mM}\right.$, $n=5-7$; Figure $7 \mathrm{~B})$ and spinal cord neurons $\left(\mathrm{IC}_{50}=0.9 \pm 0.1 \mathrm{mM}\right.$, $n=5-7$; Figure $7 \mathrm{~B})$.
The potency of TXA for inhibition of $\mathrm{GABA}_{\mathrm{A}}$ receptors and glycine receptors in cortical and spinal cord neurons is summarized in Table 2. Notably, the potency of TXA for glycine-evoked current activated by a low concentration of glycine $\left(\mathrm{EC}_{6}\right)$ was 10 -fold higher than that for glycine- and GABA-evoked currents studied under all the other experimental conditions $\left(\mathrm{F}_{6,38}=6.68\right.$, $P<0.0001$, Table 2).

Isoflurane and propofol attenuate TXA inhibition of glycine receptors. TXA-associated seizures occur most frequently as patients emerge from general anesthesia in the early postoperative period $(23,24$, $27,59)$. Thus, we postulated that the prototypic general anesthetics isoflurane (60) and propofol (39) would attenuate TXA inhibition of glycine receptors. Also, the benzodiazepine midazolam is frequently used as an anticonvulsant in the intensive care unit (61). Hence, the effect of midazolam, which selectively upregulates $\mathrm{GABA}_{\mathrm{A}}$ receptor activity but has no effect on glycine receptors (62), was studied as a negative control.

TXA ( $0.1 \mathrm{mM})$ reduced the current evoked by a low concentration of glycine to $59.7 \% \pm 2.8 \%$ of control ( $n=7$; Figure 8$)$. Coapplication of isoflurane, at clinically relevant concentrations (150 and $250 \mu \mathrm{M})$, reduced TXA inhibition as the current increased to $130.6 \% \pm 4.5 \%$ and $176.2 \% \pm 17.3 \%(n=6-7)$ of control, respectively, whereas isoflurane at a lower concentration $(50 \mu \mathrm{M}$; Figure $8 \mathrm{C})$ had no effect. In the absence of TXA, isoflurane $(150 \mu \mathrm{M}$ and $250 \mu \mathrm{M})$ potentiated glycine current, whereas isoflurane $(50 \mu \mathrm{M})$ had no effect on current amplitude (Figure 8, A and C).

Coapplication of propofol at a concentration approximating that occurring during anesthesia $(1 \mu \mathrm{M})(63)$ had no significant effect on TXA inhibition (Figure 8, B and D), while a higher concentration

\section{Figure 6}

TXA, at clinical concentrations, inhibits current evoked by low concentrations of glycine. (A) Inhibition of glycine $(10 \mu \mathrm{M})$ currents by TXA $(0.01-1 \mathrm{mM})$ in a spinal cord neuron. Application of strychnine $(1 \mu \mathrm{M})$ completely inhibited the glycine current. (B) Concentration-response plot for TXAmediated inhibition of glycine current in spinal cord neurons shows $\mathrm{IC}_{50}=93.1 \pm 2.7 \mu \mathrm{M}(n=6)$. (C) Analysis of the effect of TXA on noise shows that TXA (0.01-10 mM) significantly reduces receptor activity $(n=5-7)$. ${ }^{* \star} P<0.001$ versus 0 TXA. Data are mean \pm SEM.

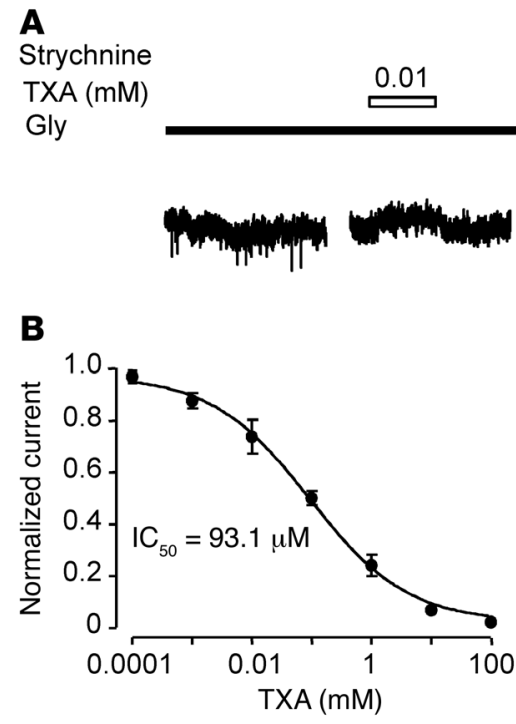

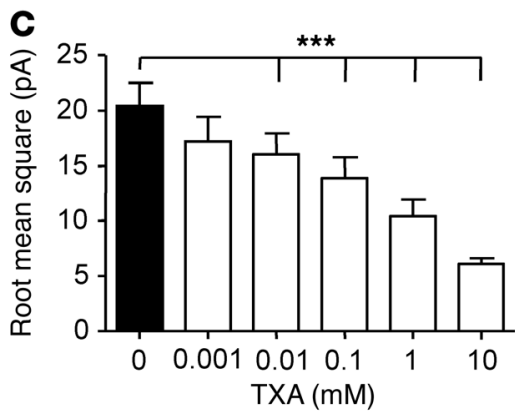


A Cortex
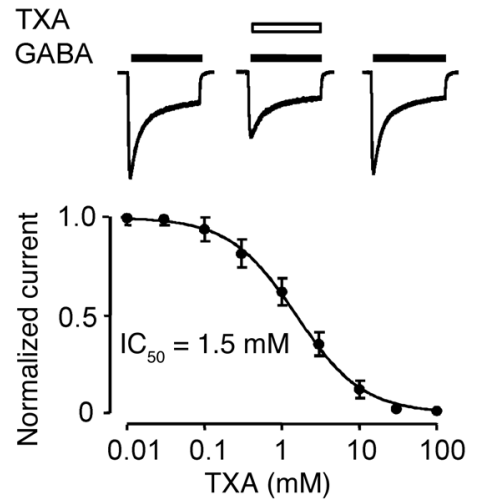

B Cortex
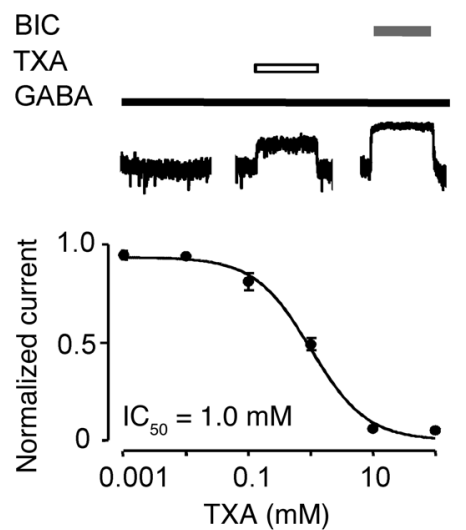

Spinal cord
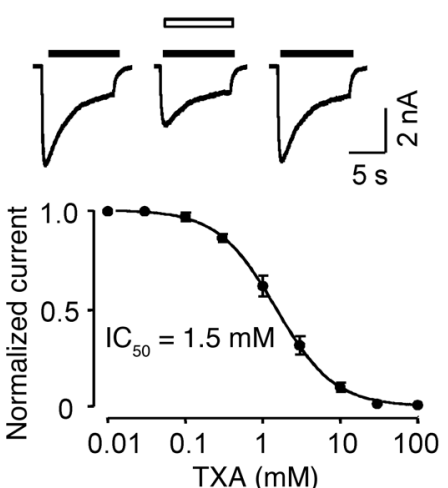

Spinal cord
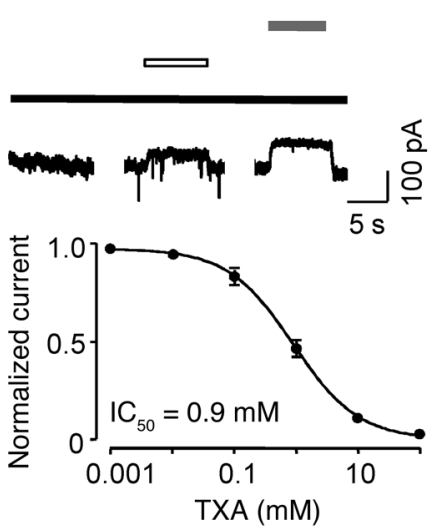

Figure 7

TXA inhibits currents evoked by high and low concentrations of GABA in cortical and spinal cord neurons. (A) TXA (1 mM) inhibits currents evoked by high $\left(E_{50}\right)$ concentrations of GABA in cortical neurons $(20 \mu \mathrm{M})$ and spinal cord neurons $(25 \mu \mathrm{M})$. The corresponding concentration-response plots show $\mathrm{IC}_{50}=1.5 \pm 0.1 \mathrm{mM}(n=4-6)$ in both the cortex and the spinal cord. (B) TXA (1 mM) also inhibits currents evoked by low concentrations of GABA $(1 \mu \mathrm{M})$ in cortical and spinal cord neurons. The corresponding concentration-response plots show $\mathrm{IC}_{50}=$ $1.0 \pm 0.1 \mathrm{mM}(n=5-7)$ in the cortex and $\mathrm{IC}_{50}=0.9 \pm 0.1 \mathrm{mM}$ $(n=5-7)$ in the spinal cord. Application of bicuculline (BIC, $100 \mu \mathrm{M})$ completely inhibited GABA current. Data are mean \pm SEM.
$(3 \mu \mathrm{M})$ reversed TXA inhibition to control levels $(101.5 \% \pm 2.3 \%$, $n=6-7$; Figure $8, \mathrm{~B}$ and D). The coapplication of propofol $(10 \mu \mathrm{M})$ and TXA enhanced the current to $183.3 \% \pm 4.6 \%$ of control $(n=6-7$; Figure $8 \mathrm{D})$. In the absence of TXA, propofol $(1 \mu \mathrm{M})$ failed to increase the baseline current, whereas higher concentrations of propofol $(3 \mu \mathrm{M}$ and $10 \mu \mathrm{M})$ increased the current amplitude (Figure 8, $\mathrm{B}$ and D). Finally, midazolam at a high concentration $(1 \mu \mathrm{M})$ had no effect on TXA-mediated inhibition (Supplemental Figure 5).

TXA increases the frequency of seizure-like events and enhances evoked field potentials in cortical slices. Previous studies have shown that disinhibition, secondary to reduced glycine receptor function, can generate spontaneous epileptiform field potentials or seizurelike events (SLEs) in cortical slices $(64,65)$. We therefore studied whether TXA would increase the frequency of SLEs, as has been shown for other pro-epileptic drugs (66-68). We employed a widely used seizure model, wherein neocortical slices are perfused with a solution containing no extracellular magnesium $\left(0 \mathrm{Mg}^{2+}\right)(69,70)$. Under these conditions, extracellular recordings in layers II or III revealed SLEs that consisted primarily of "inter-ictal" discharges (Figure 9A). The slices were then perfused with a solution containing TXA at a concentration similar to that measured in the CSF of patients $(200 \mu \mathrm{M}$, see below). Notably, protein binding of TXA is minimal (3\%) (71); thus, the effective concentration of TXA measured in the CSF of patients was equivalent to that used to perfuse the slices. We found that TXA $(200 \mu \mathrm{M})$ doubled the frequency of SLEs (control: $1.5 \mathrm{~Hz} \pm 0.4 \mathrm{~Hz}$ versus TXA: $3.7 \mathrm{~Hz} \pm 0.1 \mathrm{~Hz}, n=4$ slices; Figure 9A), which is consistent with the interpretation that TXA increases network excitability.
The proconvulsive properties of drugs can also be studied in cortical slices by recording field potentials in response to an excitatory electrical stimulus (72). Evoked field responses represent the integrated electrical activity of a large number of neurons, reflecting a combination of synchronous synaptic potentials and action potentials (73). This model provides useful information about the link between single neuron recordings and larger-scale neurophysiological signals such as electroencephalography (74). Increases in the amplitude or area of field responses in cortical networks are correlated with increased excitatory synaptic drive (73).

We investigated whether TXA enhanced the evoked field response in neocortical slices by recording field potential in layers II or III in response to electrical stimuli in layer VI. Under baseline conditions, the evoked field response was characterized by an initial stimulation artefact, followed by a brief negatively

\section{Table 2}

Summary of the $\mathrm{IC}_{50}$ values of TXA for currents evoked by high and low concentrations of glycine and GABA in the cortex and spinal cord

\begin{tabular}{lcccc}
\hline & \multicolumn{2}{c}{ Cortex } & \multicolumn{2}{c}{ Spinal cord } \\
& High $\left(\mathrm{EC}_{50}\right)$ & Low & High $\left(\mathrm{EC}_{50}\right)$ & Low \\
Glycine & $1.1 \pm 0.1$ & NA & $1.4 \pm 0.1$ & $0.09 \pm 0.01 \mathrm{~A}$ \\
GABA & $1.5 \pm 0.1$ & $1.0 \pm 0.1$ & $1.5 \pm 0.1$ & $0.9 \pm 0.1$ \\
\hline
\end{tabular}

Data are mean \pm SEM $(\mathrm{mM}) .{ }^{\mathrm{A}} \mathrm{P}<0.001$ compared with all other $\mathrm{IC}_{50}$ values. 

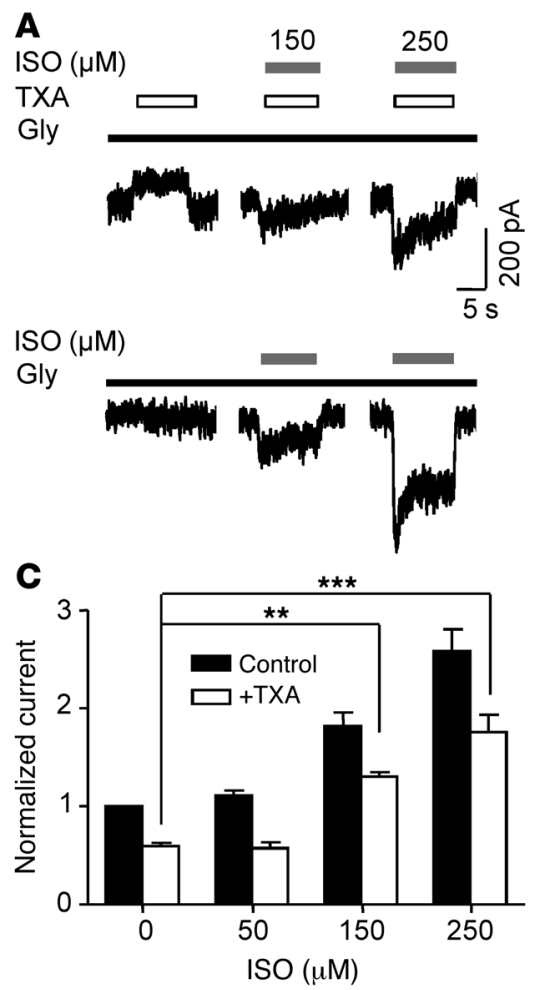

\section{B}

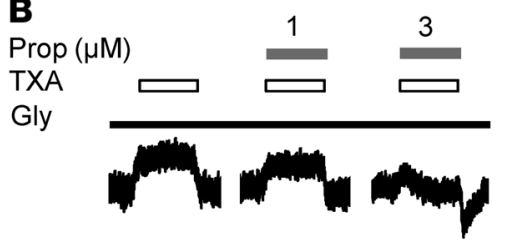

Prop $(\mu \mathrm{M})$

Gly
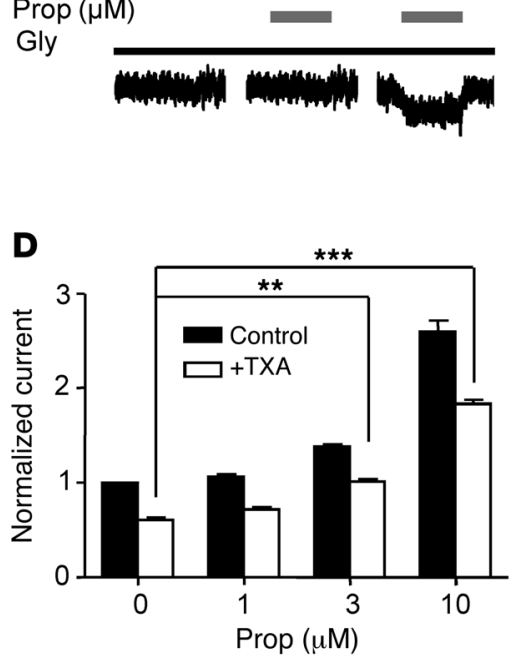

\section{Figure 8}

Isoflurane and propofol attenuate TXA inhibition of current evoked by a low concentration of glycine. (A and B) The effects of isoflurane (ISO, 150 and $250 \mu \mathrm{M}$ ) and propofol (Prop, 1 and $3 \mu \mathrm{M}$ ) on current evoked by glycine $(10 \mu \mathrm{M})$ in the presence and absence of TXA (0.1 mM). (C and $\mathbf{D})$ Isoflurane $(150$ and $250 \mu \mathrm{M})$ and propofol $(3$ and $10 \mu \mathrm{M})$ attenuated TXA-mediated inhibition of glycine current $(n=6-7)$. In the absence of TXA, isoflurane (150 and $250 \mu \mathrm{M})$ increased current amplitude to $182.2 \% \pm 13.8 \%$ and $258.7 \pm 21.8 \%$ of control, respectively. Similarly, in the absence of TXA, propofol $(3$ and $10 \mu \mathrm{M})$ increased current amplitude to $138.0 \% \pm 2.6 \%$ and $260.1 \% \pm 11.2 \%$ of control, respectively $(n=6-7)$. Lower concentrations of isoflurane $(50 \mu \mathrm{M})$ or propofol $(1 \mu \mathrm{M})$ had no effect on current amplitude. ${ }^{* *} P<0.01,{ }^{* * *} P<0.001$ versus control. Data are mean \pm SEM. directed peak (Figure 9B), as described previously (73). Perfusion of the slice with TXA $(200 \mu \mathrm{M}$, see below $)$ increased the amplitude and area of the peak responses by $59.1 \% \pm 8.0 \%$ and $85.9 \% \pm 14.9 \%$, respectively $(n=6$; Figure 9B). TXA at $1 \mathrm{mM}$ further increased the amplitude and the area of the evoked response (Figure 9B). The evoked response gradually returned to baseline after TXA washout. These results suggest that TXA causes an increase in excitatory synaptic drive.
Since glycine and $\mathrm{GABA}_{\mathrm{A}}$ receptors interact in a synchronized manner to regulate the excitability of neuronal networks, it is not possible to clearly delineate the specific contribution of each inhibitory receptor to the TXA-induced increase in network excitability. Nevertheless, we attempted to probe the relative role of glycine receptors versus $\mathrm{GABA}_{\mathrm{A}}$ receptors by perfusing the slices with either strychnine or bicuculline in the absence and presence of TXA.

\section{Figure 9}

TXA enhances SLEs and evoked field potentials in cortical slices. (A) SLEs recorded with $0 \mathrm{Mg}$ in the extracellular fluid, in the absence and presence of TXA $(200 \mu \mathrm{M})$. The bar graph shows that TXA increases the frequency but not the amplitude (control: $0.12 \pm 0.001 \mathrm{mV}$, TXA: $0.13 \pm 0.007 \mathrm{mV}$ ) of the SLEs $(n=4)$. (B) Evoked field potentials recorded in regular ACSF in the absence and presence of TXA (200 $\mu \mathrm{M}$ and $1 \mathrm{mM})$. The graphs show that both concentrations of TXA significantly increase the amplitude and the area of the evoked field responses $(n=6)$. ${ }^{\star} P<0.05,{ }^{* \star} P<0.01,{ }^{* \star \star} P<0.001$ versus control. Data are mean \pm SEM.
A Control

TXA $200 \mu \mathrm{M}$
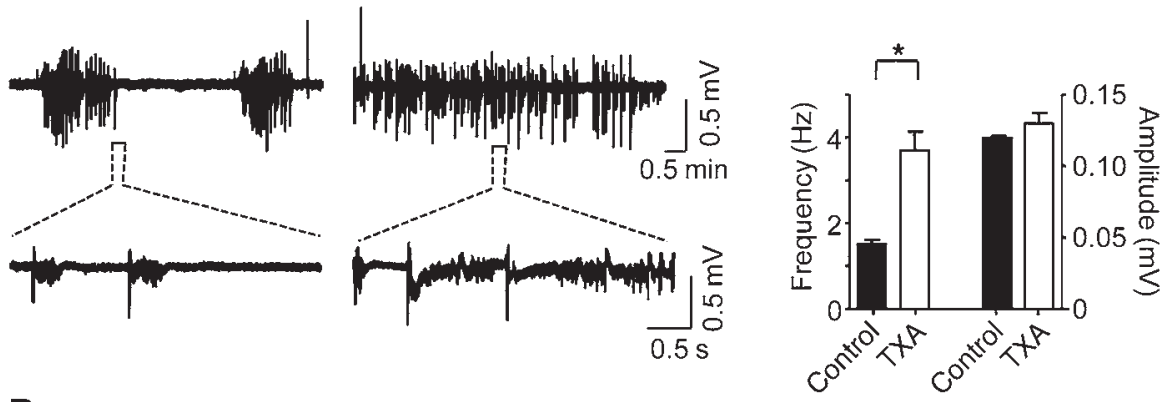

B
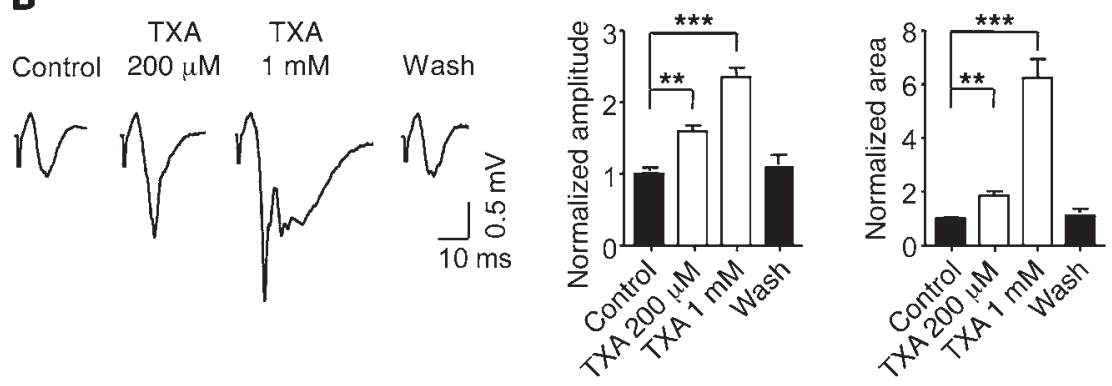
A

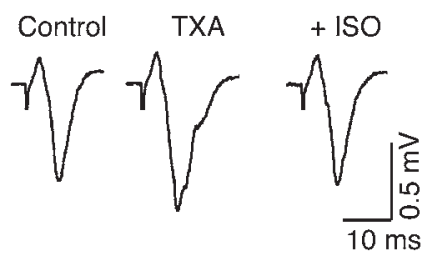

B

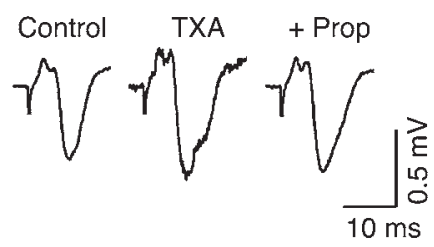

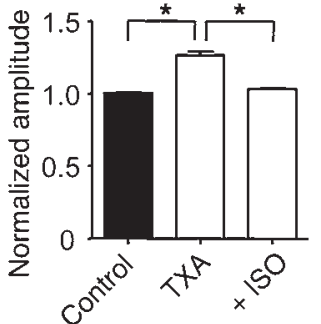
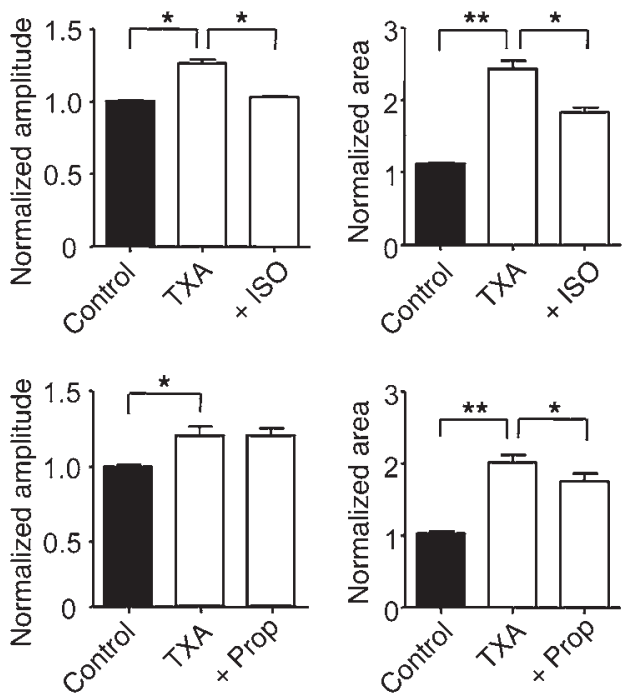

Figure 10

Isoflurane and propofol attenuate the enhancing effects of TXA on evoked field potentials in cortical slices. (A) Coapplication of isoflurane $(250 \mu \mathrm{M})$ with TXA $(200 \mu \mathrm{M})$ reverses the effect of TXA on evoked field responses. The bar graphs show that isoflurane reverses the effect on amplitude and attenuates the effect on area of evoked field responses $(n=5)$. (B) Coapplication of propofol $(1 \mu \mathrm{M})$ and TXA $(200 \mu \mathrm{M})$ also attenuates the effect of TXA on the evoked field responses. The bar graphs show that propofol attenuates the enhancing effect on area but fails to reverse the effect on amplitude $(n=5) .{ }^{*} P<0.05,{ }^{* *} P<0.01$ versus TXA. Data are mean \pm SEM.
First, to study the effect of TXA inhibition of glycine receptors on network excitability, we recorded evoked field responses in slices that were perfused with bicuculline $(10 \mu \mathrm{M})$ to block $\mathrm{GABA}_{\mathrm{A}}$ receptors. Bicuculline alone increased the amplitude to $234.2 \% \pm 5.3 \%$ and the area to $6074.0 \% \pm 214.4 \%$ of control $(n=5$; Supplemental Figure 6A). Subsequent coapplication of TXA (200 $\mu \mathrm{M}$ and $1 \mathrm{mM})$ further increased the peak amplitude of the field potentials by $10.7 \% \pm 5.4 \%$ and $29.1 \% \pm 3.7 \%$, respectively ( $n=5$; Supplemental Figure 6A), whereas the area was unchanged.

To study the contribution of $\mathrm{GABA}_{\mathrm{A}}$ receptors, we recorded evoked field responses in slices that were perfused with strychnine $(10 \mu \mathrm{M})$ to block glycine receptors. Strychnine increased the amplitude to $313.8 \% \pm 7.9 \%$ and the area to $1082.2 \% \pm 89.2 \%$ of control ( $n=5$; Supplemental Figure 6B). Coapplication of TXA $(200 \mu \mathrm{M}$ and $1 \mathrm{mM})$ further increased the area of the evoked field potentials by $190.6 \% \pm 58.4 \%$ and $213.8 \% \pm 35.7 \%$ of control, respectively ( $n=5$; Supplemental Figure $6 \mathrm{~B})$. The amplitude of the evoked response was not affected further by TXA. These results suggest that TXAmediated inhibition of both glycine receptors and $\mathrm{GABA}_{\mathrm{A}}$ receptors increases excitatory synaptic drive in the cortex.

Isoflurane is more effective than propofol at reversing TXA enhancement of evoked field potentials in cortical slices. Since we showed that isoflurane and propofol attenuate TXA-mediated inhibition of glycine receptors, we sought to determine whether these anesthetics attenuate the increase in excitatory synaptic drive induced by TXA. Coapplication of isoflurane $(250 \mu \mathrm{M})$ with TXA $(200 \mu \mathrm{M})$ fully restored the amplitude of the evoked field response to control levels and reduced the area by $61.8 \% \pm 6.7 \%$ $(n=5$; Figure 10A). Coapplication of propofol $(1 \mu \mathrm{M})$ with TXA $(200 \mu \mathrm{M})$ did not restore the amplitude of the evoked response but reversed the TXAinduced increase in area by $19.2 \% \pm 5.5 \%(n=5$;
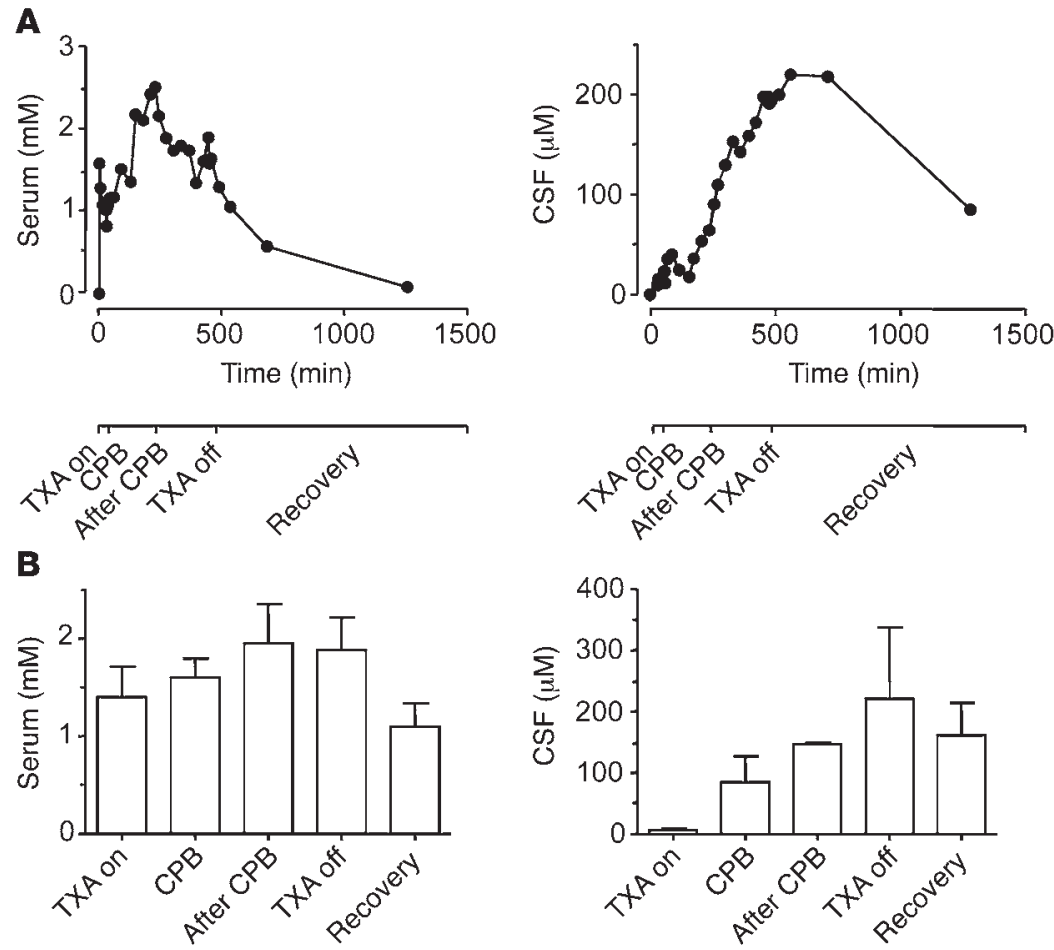

Figure 11

TXA concentrations measured in the serum and CSF of patients who underwent cardiopulmonary bypass and major vascular surgery. (A) Time-dependent plot of TXA concentration in the serum and CSF of one patient. The timeline at the bottom of the figure represents key surgical events. (B) Average TXA concentration in the serum and CSF during key surgical events $(n=4)$. Data are mean \pm SEM. 
Table 3

TXA doses and duration of the surgical events

\begin{tabular}{lccc} 
Surgical event & Description & Duration of surgical event (min) & Calculated TXA dose (mg) \\
TXA on & Time from start of TXA infusion to start of CPB & $69 \pm 38$ & $4,442 \pm 1224$ \\
CPB & Duration of CPB & $140 \pm 24$ & $3,811 \pm 544$ \\
After CPB & Time from end of CPB to end of TXA infusion & $134 \pm 35$ & $3,213 \pm 877$ \\
\hline
\end{tabular}

Data are mean \pm SEM, $n=4$.

by anesthetics could be mediated by an attenuating effect on glycine receptors or $\mathrm{GABA}_{\mathrm{A}}$ receptors, by a combination of these inhibitory receptors, or by other anesthetic targets (77).

TXA concentrations in the serum and CSF of patients. Only receptors that are sensitive to clinically relevant concentrations of TXA are plausible mediators of the adverse effects of this drug. Consequently, we sought to determine whether concentrations of TXA occurring in the CNS of patients who have received this drug would be sufficient to inhibit glycine receptors and $\mathrm{GABA}_{\mathrm{A}}$ receptors. Serum and CSF samples were obtained from patients who were undergoing repair of thoraco-abdominal pathology at certain times corresponding to procedural milestones. Serum and CSF concentrations of TXA for one patient who experienced a seizure are shown in Figure 11A. The average concentrations from the sample population are summarized in Figure 11B. The mean time points at which the serum and CSF samples were obtained and the total dose of TXA are presented in Table 3.

Surprisingly, the temporal profiles for TXA concentrations in the serum and CSF were substantially different, as indicated by the samples from a single patient (Figure 11A). The peak concentration in the serum $(1.9 \pm 0.4 \mathrm{mM}, n=4$; Figure $11 \mathrm{~B})$ occurred after cardiopulmonary bypass (CPB), whereas the peak concentration in the CSF $(220.8 \pm 116.7 \mu \mathrm{M}, n=4$, Figure 11B) occurred after discontinuation of TXA infusion. Given that less than $3 \%$ of TXA is bound to protein (71), peak concentrations in the CSF were within the range required to inhibit glycine current evoked by a low concentration of agonist $\left(\mathrm{IC}_{50}=93.1 \pm 2.7 \mu \mathrm{M}\right)$.

\section{Discussion}

To our knowledge, the study presented here is the first to identify glycine receptors as novel targets for inhibition by TXA and EACA, but not aprotinin. Because TXA is a competitive antagonist, inhibition mediated by this drug was expected to be highly dependent on the concentration of glycine applied, and this expectation was corroborated by the results. The potency of TXA was 10-fold higher for current evoked by a low concentration of glycine $\left(\mathrm{IC}_{50}=93.1 \mu \mathrm{M}\right)$ in spinal cord neurons than for postsynaptic glycinergic currents $\left(\mathrm{IC}_{50}=1 \mathrm{mM}\right)$ or currents activated by the $\mathrm{EC}_{50}$ of glycine in cortical neurons $\left(\mathrm{IC}_{50}=1.1 \mathrm{mM}\right)$ and spinal cord neurons $\left(\mathrm{IC}_{50}=1.4 \mathrm{mM}\right)$. Interestingly, the potency of TXA inhibition was similar for glycine receptors and $\mathrm{GABA}_{\mathrm{A}}$ receptors activated by the $\mathrm{EC}_{50}$ of agonist in cortical neurons and spinal cord neurons (Table 2).

We also show that TXA inhibition of glycine receptors activated by a low concentration of glycine $\left(\mathrm{EC}_{6}\right)$ was reversed by isoflurane at clinically relevant concentrations. Propofol also reversed TXAmediated glycine blockade, but only at concentrations 3-fold higher than those that occur during anesthesia (63). Consistent with these results, TXA-induced enhancement of excitatory synaptic drive in cortical slices was more effectively reversed by isoflurane than by propofol. Finally, we showed that the peak concentration of TXA in the CSF of patients undergoing major cardiovascular surgery $(220.8 \mu \mathrm{M})$ occurred after CPB and termination of drug infusion. A similar concentration of TXA increased the frequency of SLEs and enhanced evoked field responses in cortical slices, which suggests that TXA has proconvulsive properties.

Inhibitors of glycine receptors are known to induce convulsions and proconvulsive behavior (78). For example, strychnine causes myoclonic spasms (79), twitching of muscles, convulsions, and hyperreactivity (78). Genetic disorders characterized by reduced expression of glycine receptors cause hyperekplexia, convulsions, and startle disorders in infants (80). In animals with naturally occurring mutations of the glycine receptor, the magnitude of the reduction in glycine receptor function directly correlates with the severity of the convulsive symptoms $(81,82)$. Thus, it is plausible that the reduction in function of these receptors caused by TXA leads to disinhibition and proconvulsive effects.

The potency of TXA was much greater for currents evoked by a low concentration of glycine than for synaptic glycinergic mIPSCs. The demonstration that TXA attenuates tonic current is of great interest, since a reduction in tonic current enhances neuronal excitability $(36,58)$. Tonic current reduces neuronal excitability via two mechanisms. First, this type of current allows for the transfer of large quantities of negative charge, a process that hyperpolarizes the cell membrane (36). Second, tonic conductance can attenuate the excitatory drive to generate action potentials by decreasing membrane resistance, thereby reducing the amplitude of excitatory postsynaptic potentials (83).

As anticipated for a competitive antagonist, the potency of TXA inhibition of glycine receptors was highly dependent on the concentration of agonist used in each experiment. However, this difference in potency might also have been due, at least in part, to the subunit composition of glycine receptors. Glycine receptors are composed of multiple $\alpha_{1-4}$ and $\beta$ subunits, which form homomeric $(5 \alpha)$ or heteromeric $(2 \alpha 3 \beta)$ ion channels (32). Synaptic glycinergic currents are generated by heteromeric receptors that are clustered at the postsynaptic sites (35). Tonic glycinergic currents are mediated by homomeric receptors, which are located predominantly extrasynaptically (35). Glycine receptor antagonists, such as picrotoxin, show higher potency for homomeric than heteromeric glycine receptors (37). Post-transitional factors such as glycine receptor phosphorylation and the clustering of receptors in the postsynaptic domain can also alter the pharmacological properties of glycine receptors $(52,84)$. TXA potency in relation to various combinations of glycine receptor subunits as well as the effects of cytosolic regulatory factors on TXA potency are topics worthy of future study.

Our results and those of others (38) showed that TXA is a competitive antagonist of $\mathrm{GABA}_{\mathrm{A}}$ receptors in both cortical and spinal cord neurons $\left(\mathrm{IC}_{50}=1.5 \pm 0.1 \mathrm{mM}\right.$ for both). Interestingly, the potency of TXA for current evoked by a low concentration of GABA $\left(\mathrm{EC}_{4}\right)$ in cortical $\left(\mathrm{IC}_{50}=1.0 \mathrm{mM}\right)$ and spinal cord $\left(\mathrm{IC}_{50}=0.9 \mathrm{mM}\right)$ 
neurons was similar to its potency for current evoked by higher concentrations of GABA $\left(\mathrm{EC}_{50}\right)$. This result was unexpected and may reflect differences in the subunit composition of receptors activated by the various concentrations of $\operatorname{GABA}(56,57,85,86)$. In addition, our results showed that TXA inhibition of $\mathrm{GABA}_{\mathrm{A}}$ receptors increase evoked field responses in neocortical slices in the presence of strychnine. Thus, TXA inhibition of $\mathrm{GABA}_{\mathrm{A}}$ receptors may increase network excitability.

A previous study showed that TXA has an $\mathrm{IC}_{50}$ value of $7.1 \pm 3.1 \mathrm{mM}$ for recombinant $\mathrm{GABA}_{\mathrm{A}}$ receptors $(\alpha 1 \beta 2 \gamma 2)$, transfected into human embryonic kidney cells when receptors are activated by GABA $30 \mu \mathrm{M}$ $\left(E_{70}\right)$ (38). Also, binding assays for TXA with $\left[{ }^{3} \mathrm{H}\right]$ muscimol showed that the $\mathrm{IC}_{50}$ value for TXA binding to $\mathrm{GABA}_{\mathrm{A}}$ receptors was $2.1 \pm 0.2 \mathrm{mM}$ (38). In our study, the potency of TXA for GABA currents evoked by $\mathrm{EC}_{50}$ concentrations of agonist was lower. This difference may be attributable to our use of cell cultures with native receptors rather than recombinantly expressed receptors (87).

The peak TXA concentration in the CSF as measured in the current study was higher than that measured in the CSF of 4 patients undergoing CPB in a previous study $(220.8 \mu \mathrm{M}$ versus $31 \mu \mathrm{M})(88)$. In the earlier study, the TXA dose was significantly lower, and samples were taken at only two time points: 15 and 90 minutes after the start of TXA infusion (88). The discrepancy in results is probably related to two findings from the current study, specifically, that serum concentrations of TXA do not correlate well with CSF concentrations and that TXA concentrations peak in the CSF long after the start of drug infusion. Thus, the previous study may not have detected the true peak concentrations of TXA in the CSF.

The timing and magnitude of peak TXA concentrations after CPB may be attributable to increased permeability of the blood-brain barrier during and after surgery (89). In a study that used a protein marker (S100) to measure damage to the blood-brain barrier during $\mathrm{CPB}$, the highest levels of the marker occurred after termination of the bypass (90). The blood-brain barrier appears to be particularly "leaky" at the end of CPB, which could account for the delayed rise of TXA concentrations in the CSF. Thus, the CSF may act as a slow compartment, which could explain the observed time course of TXA concentrations. A detailed pharmacokinetic analysis of TXA in the plasma and CSF would be of interest in future studies.

The results of this translational preclinical study have important clinical implications. First, we have shown that TXA is a competitive antagonist of both glycine and $\mathrm{GABA}_{\mathrm{A}}$ receptors. Thus, higher brain concentrations of TXA likely increase the risk of seizure. Indeed a higher incidence of seizures occurs in patients with preoperative renal failure (91) and those receiving higher doses of TXA (30). Currently, there is no consensus regarding optimum TXA dosing, and studies are urgently needed to determine the minimal effective dose of this drug (92).

Second, our results also suggest that isoflurane or propofol may prevent or treat TXA-induced seizures in the early postoperative period. Given the variable clinical presentation and incidence of TXA-associated seizures, clinical trials comparing the efficacy of various anticonvulsant treatments are unlikely to be feasible. Our results suggest that it may be possible to use isoflurane or propofol to prevent or treat TXA-induced seizures in the early postoperative period. Inhaled anesthetics, including isoflurane, are already being used for sedation of intubated patients in the intensive care unit (93). It must be emphasized, however, that anticonvulsants with no direct effects on glycine receptors, such as midazolam, may nonetheless be effective for treating TXA-associated seizures.
Third, because glycine receptors regulate numerous functions in the CNS, their inhibition by TXA could have adverse behavioral consequences other than seizures. One potential implication is that TXA and EACA may have pro-nociceptive properties, since antagonists of glycine receptors increase nociceptive responses in both laboratory animals and patients (94). Consistent with this prediction, patients with subarachnoid hemorrhage who were treated with TXA and EACA required higher doses of analgesics than placebo-treated patients (95). Also, patients with menorrhagia treated with TXA experienced a higher incidence of headaches, abdominal pain, and back pain than placebo-treated patients (96). Furthermore, inhibition of glycine receptors causes excessive or involuntary motor activity (hyperkinesia) in laboratory animals (97) and patients (98). Myoclonic activity observed in some patients treated with TXA may result from inhibition of glycine receptors (99).

In summary, these results show that TXA and EACA inhibit glycine receptors and suggest a novel mechanism for seizures associated with cardiovascular surgery. Isoflurane may be effective for preventing or treating TXA-induced excitability in the early postoperative period. As the indications for TXA and EACA increase, we hope that these results will aid in the prevention and management of serious neurological side effects associated with these drugs.

\section{Methods}

Whole-cell patch clamp recording in cell culture. Primary cultures of embryonic cortical and spinal cord neurons were prepared from Swiss white mice. Briefly, fetal pups (E18) were removed from mice sacrificed by cervical dislocation. The cortex or spinal cord of each fetus was collected and placed in an ice-cooled culture dish. The neurons were then dissociated by mechanical titration using two Pasteur pipettes (tip diameter, 150-200 $\mu \mathrm{m}$ ) and plated on $35-\mathrm{mm}$ culture dishes at a density of about $1 \times 10^{6} \mathrm{cells} / \mathrm{ml}$. The culture dishes were coated with collagen or poly-D-lysine (Sigma-Aldrich). For the first 5 days in vitro, cells were maintained in MEM supplemented with $10 \%$ fetal bovine serum and $10 \%$ horse serum (both from Life Technologies). The neurons were cultured at $37^{\circ} \mathrm{C}$ in a $5 \% \mathrm{CO}_{2} / 95 \%$ air environment. After the background cells had grown to confluence, $0.1 \mathrm{ml}$ of a mixture of $4 \mathrm{mg} 5$-fluorodeoxyuridine and $10 \mathrm{mg}$ uridine in $20 \mathrm{ml} \mathrm{MEM}$ was added to the extracellular solution to reduce the number of dividing cells. The medium was further supplemented with $10 \%$ horse serum and was changed every 3 or 4 days. Cells were maintained in culture for 12-16 days before use. For all reported results, data were acquired from cells from at least 3 different dissections.

These experiments were performed at room temperature. Whole-cell currents were recorded under voltage clamp $(-60 \mathrm{mV})$ conditions using an Axopatch 1D amplifier (Molecular Devices) controlled with pClamp 8.0 software (Molecular Devices) via a Digidata 1322 interface (Molecular Devices). Patch pipettes were pulled from thin-walled borosilicate glass capillary tubes; these had open tip resistances of 3-5 M 2 . Patch electrodes were filled with an intracellular solution containing (in $\mathrm{mM}$ ) $140 \mathrm{CsCl}$, 10HEPES, 11 EGTA, $2 \mathrm{MgCl}_{2}, 1 \mathrm{CaCl}_{2}, 4 \mathrm{MgATP}$, and $2 \mathrm{TEA}$ ( $\mathrm{pH} 7.3$ with $\mathrm{CsOH}$, 285-295 mOsm). The extracellular solution contained (in $\mathrm{mM}$ ) $140 \mathrm{NaCl}$, $1.3 \mathrm{CaCl}_{2}, 2 \mathrm{KCl}, 1 \mathrm{MgCl}_{2}, 25 \mathrm{HEPES}$, and 28 glucose. $\mathrm{pH}$ was adjusted to 7.4 with $\mathrm{NaOH}$, and osmolarity was adjusted to $320-330 \mathrm{mOsm}$. The extracellular solution was applied to neurons by a computer-controlled, multi-barrel perfusion system (SF-77B, Warner Instruments). Membrane capacitance was measured according to the membrane test protocol in the pClamp 8.0 software. Access resistance was monitored throughout the experiments by applying a brief $10-\mathrm{mV}$ hyperpolarization during the experiments. Cells were eliminated from further analysis if the access resistance changed by about $20 \%$ or more. Tetrodotoxin (TTX, $300 \mathrm{nM}$ ) was added 
to the extracellular solution to block voltage-sensitive sodium channels, and 6-cyano-7-nitroquinoxaline-2,3-dione (CNQX, $10 \mu \mathrm{M})$ and 2-amino4-phosphonovalericacid (D-AP5, $40 \mu \mathrm{M})$ were added to inhibit the ionotropic glutamate receptors. Bicuculline $(10 \mu \mathrm{M})$ was added to block $\mathrm{GABA}_{\mathrm{A}}$ receptors when glycine current was recorded. Strychnine $(1 \mu \mathrm{M})$ was added to block glycine receptors when GABA current was measured.

To study synaptic glycine receptor-mediated currents, we added sucrose to the extracellular solution to stimulate glycine release and increase the frequency of glycinergic mIPSCs recorded from cultured spinal cord neurons. To increase the amplitude of tonic current and to facilitate its pharmacological characterization, we added glycine $\left(\mathrm{EC}_{6}=10 \mu \mathrm{M}\right)$ or GABA $\left(\mathrm{EC}_{4}=1 \mu \mathrm{M}\right)$ to the extracellular solution. These concentrations are similar to extracellular concentrations of glycine (48) and GABA (57) in the CNS.

Extracellular field potentials recorded in neocortical slices. Mice (C57BL/6J and Sv129Ev cross) at P21-P28 were anesthetized with isoflurane and decapitated. Coronal neocortical slices $(400 \mu \mathrm{m})$ were prepared using a vibratome (Leica VT $1200 \mathrm{~S})$ and placed in ice-cold, oxygenated $\left(95 \% \mathrm{O}_{2}, 5 \% \mathrm{CO}_{2}\right)$ artificial cerebrospinal fluid (ACSF) containing (in mM) $124 \mathrm{NaCl}, 3 \mathrm{KCl}, 1.3 \mathrm{MgCl}_{2}, 2.6 \mathrm{CaCl}_{2}$, $1.25 \mathrm{NaH}_{2} \mathrm{PO}_{4}, 26 \mathrm{NaHCO}_{3}$, and 10 D-glucose, with osmolarity adjusted to 300-310 mOsm. After a recovery period of 1 hour in the oxygenated ACSF, the slices were transferred to a submersion recording chamber and perfused with oxygenated ACSF, maintained at $33-34^{\circ} \mathrm{C}$, at a perfusion rate of $3-4 \mathrm{ml} / \mathrm{min}$.

To demonstrate that TXA exhibits proconvulsant properties, we used the widely accepted $0 \mathrm{Mg}^{+2}$ seizure model $(69,70)$. Slices were perfused with ACSF from which $\mathrm{MgCl}_{2}$ was omitted (designated $0 \mathrm{Mg}^{2+}$ ). Recording electrodes were filled with ACSF and placed in layer II or III of the cortex. SLEs, or spontaneous high-frequency rhythmic potentials, which are typically observed in this model (100), were recorded under gap-free conditions using a Multiclamp 700A amplifier (Molecular Devices) in the current-clamp configuration. SLEs are traditionally divided into "ictal" states, defined as the onset of high-frequency rhythmic field discharges, and "interictal" states, defined as the low-frequency discharges that occur in the period between ictal states $(100,101)$. It is not uncommon for SLEs recorded in the neocortex to lack full ictal events (101). Indeed, we were only able to record interictal events in this preparation.

Evoked field responses were recorded in layers II or III of the neocortex with recording electrodes filled with standard ACSF and were monitored in each slice for 20 minutes or until the response stabilized. A concentric bipolar stimulating electrode (Rhodes Medical Instruments) was used to stimulate layer VI of the neocortex. Responses were evoked at $0.05 \mathrm{~Hz}$ at an intensity that yielded a half-maximal field potential amplitude. Evoked field responses were recorded in standard ACSF.

Data analysis. Currents were analyzed with pClamp 10 software (Molecular Devices). The glycine concentration-response plot was fitted to the modified Michaelis-Menten equation: $I=I_{\max } /\left[1+\left(\mathrm{EC}_{50} / c\right)^{n \mathrm{H}}\right]$, where $I$ is the current amplitude, $c$ is the concentration of agonist, $\mathrm{EC}_{50}$ is the concentration of agonist that produces currents with $50 \%$ of maximal amplitude, and $n \mathrm{H}$ is the estimated Hill coefficient. The reversal potential for $\mathrm{Cl}^{-}$ was calculated with the Nernst equation: $\mathrm{E}_{\mathrm{Cl}^{-}}=58 \log \left[\mathrm{Cl}^{-}\right]_{\text {inside }} /\left[\mathrm{Cl}^{-}\right]_{\text {outside }}$. Schild regression analysis was performed by calculating the dose-response ratios of antagonist $\mathrm{EC}_{50}$ to agonist $\mathrm{EC}_{50}$ for each concentration of TXA; the log of the concentration-response ratio was then plotted against the log of TXA concentration. The slope of the Schild plot was used to determine the nature of antagonism, given that competitive antagonists would generate a slope of 1 . The $x$-intercept of the fitted regression line was used to calculate the equilibrium dissociation constant, which estimates the affinity of TXA for the glycine receptor (102).

To assess the effect of the drugs on synaptic glycinergic conductance, mIPSCs were analyzed with Mini Analysis software (Synaptosoft). For detection of mIPSCs, the threshold was set at approximately 3 times the level of baseline noise ( 3.6 pA). However, compound events (i.e., those with multiple peaks) were excluded from the analysis. Manual inspection of each file was also performed, to allow rejection of false events caused by noise and inclusion of events that were not detected automatically. At least 100 individual mIPSC events were detected under each experimental condition. The peak amplitude, frequency, rise time, decay time $(\tau)$, area, and charge transfer were analyzed. Peak amplitude refers to the maximum height of the mIPSC, and the frequency was calculated by determining the inter-event interval. The rise time refers to the time elapsed between $10 \%$ and $90 \%$ of the peak amplitude response. The decay $\tau$ was determined using the biexponential equation $I(t)=A_{1} \exp \left(-t / \tau_{1}\right)+$ $\mathrm{A}_{2} \exp \left(-t / \tau_{2}\right)$, where $I$ is the current amplitude at any given time $(t) ; \mathrm{A}_{1}$ and $\mathrm{A}_{2}$ are the amplitudes of the fast and slow decay components, respectively; and $\tau_{1}$ and $\tau_{2}$ are their respective decay time constants. The weighted time constant of current decay was determined by the equation $\tau_{\text {decay }}=\sum \mathrm{A}_{\mathrm{i}} \tau_{\mathrm{i}} / \Sigma \mathrm{A}_{\mathrm{i}}$. Area was determined by integrating the area under the MIPSC curve. Charge transfer was determined by multiplying the frequency by the area of the mIPSCs (51). Cumulative distribution plots of mIPSC amplitudes and frequency were generated in GraphPad Prism 5 (GraphPad Software Inc.).

The amplitude of tonic glycine current was measured as the difference in the holding current before and during application of strychnine $(1 \mu \mathrm{M})$, while the amplitude of tonic GABA current was measured by application of bicuculline $(100 \mu \mathrm{M})$. Drug efficacy was reported as percentage of control, where control was equal to the amplitude of the tonic current revealed by application of either strychnine or bicuculline. The variance of baseline noise, measured for tonic glycine current, was determined by the root mean square deviation from the recording segments that lacked mIPSCs, as previously described $(51,58)$.

SLEs and evoked field potentials were analyzed using GraphPad Prism 5. The frequency of SLEs was determined using pClamp 10 data acquisition and analysis software (Molecular Devices). The threshold for event detection was set at $\sim 0.5 \mathrm{mV}$.

Drugs and chemicals. TXA and EACA were obtained from Sigma-Aldrich, while aprotinin (Trasylol) was purchased from Bayer. Propofol (Diprivan) and midazolam were purchased from AstraZeneca, while isoflurane was obtained from Abbott Laboratories. Tetrodotoxin was purchased from Alomone Laboratories; CNQX, D-AP5, bicuculline, strychnine, and glycine were obtained from Sigma-Aldrich. Propofol and midazolam were each diluted in extracellular solution as previously described (103). Isoflurane solutions were prepared and applied as previously described (104). The highest concentration of isoflurane in the undiluted aqueous solution was $2,500 \mu \mathrm{M}$. The aqueous phase concentration of isoflurane equivalent to minimal alveolar concentrations in vitro studies at room temperature is $253-280 \mu \mathrm{M}(105,106)$. Stock solutions of all other reagents were prepared with distilled water.

Patients and surgical procedures. Patients included in the study were ages 19-85, inclusive, and scheduled for open thoraco-abdominal aortic surgery, with planned placement of a lumbar CSF drain and intraoperative use of TXA. This is a complex procedure that is performed in a selected number of specialized surgical centers. Due to the known variability in duration of the procedure and operative techniques, and since the amount of CSF available for study is limited, samples were obtained at predetermined procedural milestones. TXA dosing was in accordance with recommended protocols (13), with a loading dose of $30 \mathrm{mg} / \mathrm{kg}$ plus additional $2 \mathrm{mg} / \mathrm{kg}$ added to the CPB prime followed by $16 \mathrm{mg} / \mathrm{kg} / \mathrm{h}$ infusion until chest closure. TXA concentrations in serum and CSF were quantified using a modified liquid chromatography and a tandem mass spectrometry assay $(88,107)$. At a functional coefficient of variance of $20 \%$, the minimum detectable level of TXA is $0.05 \mu \mathrm{g} / \mathrm{ml}$.

Statistics. GraphPad Prism 5 was used to generate the bar graphs. Results are presented as mean \pm SEM. Differences between groups were determined using a 1-tailed Student $t$ test, 1-way ANOVA with a Dunnett mul- 
tiple comparison post hoc test, or 2-way ANOVA with Bonferroni post hoc test. Cumulative distribution plots of mIPSCs were analyzed with the Kolmogorov-Smirnov test. A $P$ value of less than 0.05 was considered significant.

Study approval. All animal experiments were approved by the Animal Care Committee of the University of Toronto. The human study protocol was approved by the Research Ethics Board of St. Michael's Hospital, Toronto, Ontario, Canada. Written and informed consent was obtained from all patients.

\section{Acknowledgments}

This work was supported by operating grants from the Canadian Institute of Health Research (MOP-38028, MOP-79428) and a grant from the Canadian Anaesthesiologists' Society to B.A. Orser. I. Lecker was supported by a Savoy Foundation studentship. B.A.
Orser holds a Canada Research Chair. We are grateful to Laura A. Burns and Sanjay Yagnik for patient enrollment, data collection, and data analysis. We thank Ella Czerwinski for her assistance with the cell cultures. The authors would also like to thank Liang Zhang for his advice and unwavering support.

Received for publication February 17, 2012, and accepted in revised form September 4, 2012.

Address correspondence to: Beverley A. Orser, Department of Physiology, University of Toronto, Room 3318, Medical Sciences Building, 1 King's College Circle, Toronto, Ontario, Canada, M5S1A8. Phone: 416.978.1518; Fax: 416.480.6039; E-mail: Beverley. orser@utoronto.ca.
1. Shakur H, et al. Effects of tranexamic acid on death, vascular occlusive events, and blood transfusion in trauma patients with significant haemorrhage (CRASH-2): a randomised, placebo-controlled trial. Lancet. 2010;376(9734):23-32.

2. Zufferey PJ, et al. Tranexamic acid in hip fracture surgery: a randomized controlled trial. BrJ Anaesth. 2010;104(1):23-30.

3. Rannikko A, Petas A, Taari K. Tranexamic acid in control of primary hemorrhage during transurethral prostatectomy. Urology. 2004;64(5):955-958.

4. Neilipovitz DT. Tranexamic acid for major spinal surgery. Eur Spine J. 2004;13(suppl 1):S62-S65.

5. Rahman Z, Hoque R, Ali A, Rahman M, Rahman MS. Blood conservation strategies for reducing peri-operative blood loss in open heart surgery. Mymensingh Med J. 2011;20(1):45-53.

6. Ducloy-Bouthors AS, et al. High-dose tranexamic acid reduces blood loss in postpartum haemorrhage. Crit Care. 2011;15(2):R117.

7. Koch CG, et al. Morbidity and mortality risk associated with red blood cell and blood-component transfusion in isolated coronary artery bypass grafting. Crit Care Med. 2006;34(6):1608-1616

8. Blanchette CM, et al. Cost and utilization of blood transfusion associated with spinal surgeries in the United States. Eur Spine J. 2007;16(3):353-363.

9. Martinez MC. Management of scarce resources in blood services in developing countries. Vox Sang. 2002;83(suppl 1):137-140.

10. Henry DA, et al. Anti-fibrinolytic use for minimising perioperative allogeneic blood transfusion. Cochrane Database Syst Rev. 2011;3(3):CD001886.

11. Iwamoto M. Plasminogen-plasmin system IX. Specific binding of tranexamic acid to plasmin. Thromb Diath Haemorrh. 1975;33(3):573-585.

12. McEvoy MD, Reeves ST, Reves JG, Spinale FG. Aprotinin in cardiac surgery: a review of conventional and novel mechanisms of action. Anesth Analg. 2007;105(4):949-962.

13. Fergusson DA, et al. A comparison of aprotinin and lysine analogues in high-risk cardiac surgery. NEngl J Med. 2008;358(22):2319-2331.

14. Mangano DT, Tudor IC, Dietzel C. The risk associated with aprotinin in cardiac surgery. NEnglJ Med. 2006;354(4):353-365

15. Shaw AD, et al. The effect of aprotinin on outcome after coronary-artery bypass grafting. $N$ Engl J Med. 2008;358(8):784-793.

16. Pellegrini A, Giaretta D, Chemello R, Zanotto L, Testa G. Feline generalized epilepsy induced by tranexamic acid (AMCA). Epilepsia. 1982;23(1):35-45.

17. Schlag MG, Hopf R, Redl H. Convulsive seizures following subdural application of fibrin sealant containing tranexamic acid in a rat model. Neurosurgery. 2000;47(6):1463-1467.

18. Schlag MG, Hopf R, Zifko U, Redl H. Epileptic seizures following cortical application of fibrin sealants containing tranexamic acid in rats. Acta
Neurochir(Wien). 2002;144(1):63-69.

19. de Leede-van der Maarl MG, Hilkens P, Bosch F. The epileptogenic effect of tranexamic acid. J Neurol. 1999;246(9):843.

20. Mohseni K, Jafari A, Nobahar MR, Arami A. Polymyoclonus seizure resulting from accidental injection of tranexamic acid in spinal anesthesia. Anesth Analg. 2009;108(6):1984-1986.

21. Yeh HM, Lau HP, Lin PL, Sun WZ, Mok MS. Convulsions and refractory ventricular fibrillation after intrathecal injection of a massive dose of tranexamic acid. Anesthesiology. 2003;98(1):270-272.

22. Feffer SE, Parray HR, Westring DW. Seizure after infusion of aminocaproic acid. JAMA. 1978; 240(22):2468.

23. Murkin JM, et al. High-dose tranexamic acid is associated with nonischemic clinical seizures in cardiac surgical patients. Anesth Analg. 2010;110(2):350-353.

24. Keyl C, et al. High-dose tranexamic acid is related to increased risk of generalized seizures after aortic valve replacement. Eur J Cardiothorac Surg. 2011; 39(5):e114-e121.

25. Goldstone AB, et al. Predictors and outcomes of seizures after cardiac surgery: a multivariable analysis of 2,578 patients. Ann Thorac Surg. 2011; 91(2):514-518.

26. Roach GW, et al. Adverse cerebral outcomes after coronary bypass surgery. Multicenter Study of Perioperative Ischemia Research Group and the Ischemia Research and Education Foundation Investigators. N Engl J Med. 1996;335(25):1857-1863.

27. Sander M, et al. Mortality associated with administration of high-dose tranexamic acid and aprotinin in primary open-heart procedures: a retrospective analysis. Crit Care. 2010;14(4):R148.

28. Martin K, et al. Seizures after open heart surgery: comparison of $\varepsilon$-aminocaproic acid and tranexamic acid. J Cardiothorac Vasc Anesth. 2011;25(1):20-25.

29. Manji RA, et al. Seizures following cardiac surgery: the impact of tranexamic acid and other risk factors. Can J Anaesth. 2012;59(1):6-13.

30. Kalavrouziotis D, Voisine P, Mohammadi S, Dionne S, Dagenais F. High-dose tranexamic acid is an independent predictor of early seizure after cardiopulmonary bypass. Ann Thorac Surg. 2012; 93(1):148-154.

31. Hunter GR, Young GB. Seizures after cardiac surgery. J Cardiothorac Vasc Anesth. 2011;25(2):299-305.

32. Betz H, Laube B. Glycine receptors: recent insights into their structural organization and functional diversity. J Neurochem. 2006;97(6):1600-1610.

33. Colquhoun D, Sivilotti LG. Function and structure in glycine receptors and some of their relatives. Trends Neurosci. 2004;27(6):337-344.

34. Lynch JW. Molecular structure and function of the glycine receptor chloride channel. Physiol Rev. 2004;84(4):1051-1095.

35. Muller E, Le-Corronc H, Legendre P, Muller E, LeCorronc H, Legendre P. Extrasynaptic and post- synaptic receptors in glycinergic and GABAergic neurotransmission: a division of labor? Front Mol Neurosci. 2008; $1: 3$

36. Takazawa T, MacDermott AB. Glycinergic and GABAergic tonic inhibition fine tune inhibitory control in regionally distinct subpopulations of dorsal horn neurons. J Physiol. 2010; 588(pt 14):2571-2587.

37. Lynch JW. Native glycine receptor subtypes and their physiological roles. Neuropharmacology. 2009; 56(1):303-309.

38. Furtmuller R, et al. Tranexamic acid, a widely used antifibrinolytic agent, causes convulsions by a $\gamma$-aminobutyric acid $\mathrm{A}_{\mathrm{A}}$ receptor antagonistic effect. J Pharmacol Exp Ther. 2002;301(1):168-173.

39. Hales TG, Lambert JJ. The actions of propofol on inhibitory amino acid receptors of bovine adrenomedullary chromaffin cells and rodent central neurones. Br J Pharmacol. 1991;104(3):619-628.

40. Ahrens J, et al. A transmembrane residue influences the interaction of propofol with the strychnine-sensitive glycine $\alpha 1$ and $\alpha 1 \beta$ receptor. Anesth Analg. 2008; 107(6):1875-1883.

41. Downie DL, Hall AC, Lieb WR, Franks NP. Effects of inhalational general anaesthetics on native glycine receptors in rat medullary neurones and recombinant glycine receptors in Xenopus oocytes. Br J Pharmacol. 1996;118(3):493-502.

42. Fedorow CA, Moon MC, Mutch WA, Grocott HP. Lumbar cerebrospinal fluid drainage for thoracoabdominal aortic surgery: rationale and practical considerations for management. Anesth Analg. 2010; 111(1):46-58.

43. Cina CS, et al. Cerebrospinal fluid drainage to prevent paraplegia during thoracic and thoracoabdominal aortic aneurysm surgery: a systematic review and meta-analysis. J Vasc Surg. 2004; 40(1):36-44.

44. MacDonald JF, Miljkovic Z, Pennefather P. Usedependent block of excitatory amino acid currents in cultured neurons by ketamine. J Neurophysiol. 1987; 58(2):251-266.

45. Jin X, Covey DF, Steinbach JH. Kinetic analysis of voltage-dependent potentiation and block of the glycine $\alpha 3$ receptor by a neuroactive steroid analogue. JPhysiol. 2009;587(pt 5):981-997.

46. Later AF, et al. Tranexamic acid and aprotinin in low- and intermediate-risk cardiac surgery: a non-sponsored, double-blind, randomised, placebo-controlled trial. Eur J Cardiothorac Surg. 2009; 36(2):322-329.

47. Caraiscos VB, et al. Insulin increases the potency of glycine at ionotropic glycine receptors. Mol Pharmacol. 2007;71(5):1277-1287.

48. Whitehead KJ, Manning JP, Smith CG, Bowery NG. Determination of the extracellular concentration of glycine in the rat spinal cord dorsal horn by quantitative microdialysis. Brain Res. 2001;910(1-2):192-194.

49. Meier JC, et al. RNA editing produces glycine recep- 
tor $\alpha 3(\mathrm{P} 185 \mathrm{~L})$, resulting in high agonist potency. Nat Neurosci. 2005;8(6):736-744.

50. Ataka T, Gu JG. Relationship between tonic inhibitory currents and phasic inhibitory activity in the spinal cord lamina II region of adult mice. Mol Pain. 2006;2:36.

51. Bai D, et al. Distinct functional and pharmacological properties of tonic and quantal inhibitory postsynaptic currents mediated by $\gamma$-aminobutyric $\mathrm{acid}_{\mathrm{A}}$ receptors in hippocampal neurons. Mol Pharmacol. 2001;59(4):814-824.

52. Legendre P, et al. Desensitization of homomeric $\alpha 1$ glycine receptor increases with receptor density. Mol Pharmacol. 2002;62(4):817-827.

53. Chang Y, Ghansah E, Chen Y, Ye J, Weiss DS. Desensitization mechanism of GABA receptors revealed by single oocyte binding and receptor function. J Neurosci. 2002;22(18):7982-7990.

54. Takahashi A, Mashimo T, Uchida I. GABAergic tonic inhibition of substantia gelatinosa neurons in mouse spinal cord. Neuroreport. 2006; 17(12):1331-1335

55. Vardya I, Drasbek KR, Dosa Z, Jensen K. Cell typespecific $\mathrm{GABA}_{\mathrm{A}}$ receptor-mediated tonic inhibition in mouse neocortex. J Neurophysiol. 2008; 100(1):526-532.

56. Caraiscos VB, et al. Tonic inhibition in mouse hippocampal CA1 pyramidal neurons is mediated by $\alpha 5$ subunit-containing $\gamma$-aminobutyric acid type A receptors. Proc Natl Acad Sci U S A. 2004; 101(10):3662-3667.

57. Yeung JY, et al. Tonically activated GABAA receptors in hippocampal neurons are high-affinity, low-conductance sensors for extracellular GABA. Mol Pharmacol. 2003;63(1):2-8.

58. Bonin RP, Martin LJ, MacDonald JF, Orser BA. $\alpha 5 \mathrm{GABA}_{\mathrm{A}}$ receptors regulate the intrinsic excitability of mouse hippocampal pyramidal neurons J Neurophysiol. 2007;98(4):2244-2254.

59. Casati V, Romano A, Novelli E, D’Angelo A. Tranexamic acid for trauma. Lancet. 2010; 376(9746):1049-1050; author reply 1050-1041.

60. Lobo IA, Harris RA. Sites of alcohol and volatile anesthetic action on glycine receptors. Int Rev Neu robiol. 2005;65:53-87.

61 . Bleck TP. Intensive care unit management of patients with status epilepticus. Epilepsia. 2007; 48(suppl 8):59-60

62. Kohno T, et al. Actions of midazolam on GABAergic transmission in substantia gelatinosa neurons of adult rat spinal cord slices. Anesthesiology. 2000; 92(2):507-515

63. Rehberg B, Duch DS. Suppression of central nervous system sodium channels by propofol. Anesthesiology. 1999;91(2):512-520.

64. Kirchner A, Breustedt J, Rosche B, Heinemann UF, Schmieden V. Effects of taurine and glycine on epileptiform activity induced by removal of $\mathrm{Mg}^{2+}$ in combined rat entorhinal cortex-hippocampal slices. Epilepsia. 2003;44(9):1145-1152.

65. Straub H, Kohling R, Speckmann EJ. Strychnineinduced epileptiform activity in hippocampal and neocortical slice preparations: suppression by the organic calcium antagonists verapamil and flunarizine. Brain Res. 1997;773(1-2):173-180.

66. Alger BE, Nicoll RA. Epileptiform burst afterhyperolarization: calcium-dependent potassium potential in hippocampal CA1 pyramidal cells. Science. 1980;210(4474):1122-1124.

67. Schwartzkroin PA, Prince DA. Changes in excitatory and inhibitory synaptic potentials leading to epileptogenic activity. Brain Res. 1980;183(1):61-76.

68. Dingledine R, Gjerstad L. Reduced inhibition during epileptiform activity in the in vitro hippocampal slice. J Physiol. 1980;305:297-313.

69. Mody I, Lambert JD, Heinemann U. Low extracellular magnesium induces epileptiform activity and spreading depression in rat hippocampal slices. J Neurophysiol. 1987;57(3):869-888.

70. Walther H, Lambert JD, Jones RS, Heinemann U, Hamon B. Epileptiform activity in combined slices of the hippocampus, subiculum and entorhinal cortex during perfusion with low magnesium medium. Neurosci Lett. 1986;69(2):156-161.

71. McCormack PL. Tranexamic acid: a review of its use in the treatment of hyperfibrinolysis. Drugs. 2012; 72(5):585-617.

72. Schwartzkroin PA, Prince DA. Penicillin-induced epileptiform activity in the hippocampal in vitro prepatation. Ann Neurol. 1977;1(5):463-469.

73. David SV, Malaval N, Shamma SA. Decoupling action potential bias from cortical local field potentials. Comput Intell Neurosci. 2010;2010:393019.

74. Buzsaki G, Anastassiou CA, Koch C. The origin of extracellular fields and currents-EEG, ECoG, LFP and spikes. Nat Rev Neurosci. 2012;13(6):407-420.

75. Becker K, et al. Low dose isoflurane exerts opposing effects on neuronal network excitability in neocortex and hippocampus. PLoS One. 2012;7(6):e39346.

76. Ohmori H, Sato Y, Namiki A. The anticonvulsant action of propofol on epileptiform activity in rat hippocampal slices. Anesth Analg. 2004; 99(4):1095-1101.

77. Hemmings HC Jr. Sodium channels and the synaptic mechanisms of inhaled anaesthetics. $\mathrm{Br} \mathrm{J}$ Anaesth. 2009;103(1):61-69.

78. Parker AJ, Lee JB, Redman J, Jolliffe L. Strychnine poisoning: gone but not forgotten. Emerg Med J. 2011; 28(1):84

79. Young AB, Snyder SH. Strychnine binding associated with glycine receptors of the central nervous system. Proc Natl Acad Sci U S A. 1973 70(10):2832-2836.

80. Chung SK, et al. Pathophysiological mechanisms of dominant and recessive GLRA1 mutations in hyperekplexia. J Neurosci. 2010;30(28):9612-9620.

81. Gundlach AL, et al. Deficit of spinal cord glycine/ strychnine receptors in inherited myoclonus of Poll Hereford calves. Science. 1988;241(4874):1807-1810.

82. Graham BA, Schofield PR, Sah P, Margrie TW, Callister RJ. Distinct physiological mechanisms underlie altered glycinergic synaptic transmission in the murine mutants spastic, spasmodic, and oscillator. J Neurosci. 2006;26(18):4880-4890.

83. Mitchell SJ, Silver RA. Shunting inhibition modulates neuronal gain during synaptic excitation. Neuron. 2003;38(3):433-445.

84. Caraiscos VB, Mihic SJ, MacDonald JF, Orser BA. Tyrosine kinases enhance the function of glycine receptors in rat hippocampal neurons and human $\alpha 1 \beta$ glycine receptors. J Physiol. 2002 539(pt 2):495-502.

85. Liang J, Cagetti E, Olsen RW, Spigelman I. Altered pharmacology of synaptic and extrasynaptic $\mathrm{GABA}_{\mathrm{A}}$ receptors on CA1 hippocampal neurons is consistent with subunit changes in a model of alcohol withdrawal and dependence. J Pharmacol Exp Ther. 2004;310(3):1234-1245.

86. Walker MC. $\mathrm{GABA}_{\mathrm{A}}$ receptor subunit specificity: a tonic for the excited brain. J Physiol. 2008; 586(4):921-922.

87. Mathers DA. Activation and inactivation of the $\mathrm{GABA}_{\mathrm{A}}$ receptor: insights from comparison of native and recombinant subunit assemblies. Can J Physiol Pharmacol. 1991;69(7):1057-1063.

88. Abou-Diwan C, et al. Plasma and cerebral spinal fluid tranexamic acid quantitation in cardiopulmonary bypass patients. J Chromatogr B Analyt Technol
Biomed Life Sci. 2011;879(7-8):553-556.

89. Gillinov AM, et al. Cardiopulmonary bypass and the blood-brain barrier. An experimental study. J Thorac Cardiovasc Surg. 1992;104(4):1110-1115.

90. Grocott HP, Arrowsmith JE. Serum S100 protein as a marker of cerebral damage during cardiac surgery. BrJ Anaesth. 2001;86(2):289-290.

91. Montes FR, et al. Risk factors associated with postoperative seizures in patients undergoing cardiac surgery who received tranexamic acid: a case-control study. Ann Card Anaesth. 2012;15(1):6-12.

92. Lecker I, Orser BA, Mazer CD. "Seizing" the opportunity to understand antifibrinolytic drugs. Can J Anaesth. 2012;59(1):1-5.

93. Sackey PV, Martling CR, Granath F, Radell PJ. Prolonged isoflurane sedation of intensive care unit patients with the Anesthetic Conserving Device. Crit Care Med. 2004;32(11):2241-2246.

94. Sivilotti L, Woolf CJ. The contribution of GABA and glycine receptors to central sensitization: disinhibition and touch-evoked allodynia in the spinal cord. J Neurophysiol. 1994;72(1):169-179.

95. Kassell NF, Torner JC, Adams HP Jr. Antifibrinolytic therapy in the acute period following aneurysmal subarachnoid hemorrhage. Preliminary observations from the Cooperative Aneurysm Study. J Neurosurg. 1984;61(2):225-230.

96. Lukes AS, Freeman EW, Van Drie D, Baker J, Adomako TL. Safety of tranexamic acid in women with heavy menstrual bleeding: an open-label extension study. Women's Health (Lond Engl). 2011;7(5):591-598.

97. Gundlach AL. Disorder of the inhibitory glycine receptor: inherited myoclonus in Poll Hereford calves. FASEB J. 1990;4(10):2761-2766.

98. Simon ES. Phenotypic heterogeneity and disease course in three murine strains with mutations in genes encoding for $\alpha 1$ and $\beta$ glycine receptor subunits. Mov Disord. 1997;12(2):221-228.

99. Hui AC, Wong TY, Chow KM, Szeto CC. Multifocal myoclonus secondary to tranexamic acid. J Neurol Neurosurg Psychiatry. 2003;74(4):547.

100.Zhang ZJ, et al. Transition to seizure: ictal discharge is preceded by exhausted presynaptic GABA release in the hippocampal CA3 region. J Neurosci. 2012; 32(7):2499-2512

101. Trevelyan AJ, Sussillo D, Watson BO, Yuste R. Modular propagation of epileptiform activity: evidence for an inhibitory veto in neocortex. J Neurosci. 2006;26(48):12447-12455.

102. Wyllie DJ, Chen PE. Taking the time to study competitive antagonism. Br J Pharmacol. 2007; 150(5):541-551.

103. McAdam LC, MacDonald JF, Orser BA. Isobolographic analysis of the interactions between midazolam and propofol at $\mathrm{GABA}_{\mathrm{A}}$ receptors in embryonic mouse neurons. Anesthesiology. 1998; 89(6):1444-1454.

104. Joo DT, et al. Blockade of AMPA receptors and volatile anesthetics: reduced anesthetic requirements in GluR2 null mutant mice for loss of the righting reflex and antinociception but not minimum alveolar concentration. Anesthesiology. 2001;94(3):478-488.

105. Franks NP, Lieb WR. Which molecular targets are most relevant to general anaesthesia? Toxicol Lett. 1998;100:1-8.

106. Caraiscos VB, et al. Selective enhancement of tonic GABAergic inhibition in murine hippocampal neurons by low concentrations of the volatile anesthetic isoflurane. J Neurosci. 2004;24(39):8454-8458.

107. Chang Q, Yin OQ, Chow MS. Liquid chromatography-tandem mass spectrometry method for the determination of tranexamic acid in human plasma. J Chromatogr B Analyt Technol Biomed Life Sci. 2004;805(2):275-280. 